\title{
Public Ideas: Their VARIETIES ANd Careers**
}

\author{
Tim Hallett, Indiana University \\ Orla Stapleton, Indiana University \\ Michael Sauder, University of Iowa
}

\begin{abstract}
Hallett, Tim, Orla Stapleton, and Michael Sauder. 2019. "Public Ideas: Their Varieties and Careers." American Sociological Review. (Online First) https://doi.org/10.1177/0003122419846628
\end{abstract}

\begin{abstract}
In light of ongoing concerns about the relevance of scholarly activities, we ask, what are public ideas and how do they come to be? More specifically, how do journalists and other mediators between the academy and the public use social science ideas? How do the various uses of these ideas develop over time and shape the public careers of these ideas? How do these processes help us to understand public ideas and to identify their various types? In addressing these questions, we make the case for a sociology of public social science. Using data from newspaper articles that engage with seven of the most publicly prominent social science ideas over the last 30 years, we make three contributions. First, we advance a pragmatic, cultural approach to understanding public ideas, one that emphasizes fit-making processes and applicative flexibility. Second, we define public ideas: social science ideas become public ideas when they are used as objects of interest (being the news), are used as interpretants (making sense of the news), and ebb and flow between these uses as part of an unfolding career. Third, we construct a typology of public ideas that provides an architecture for future research on public social science.
\end{abstract}

Keywords: Public ideas, public social science, cultural objects, applicative flexibility, sociology of public social science.

Corresponding Author: Tim Hallett, Indiana University, Department of Sociology, Ballantine Hall 774, Bloomington, IN 47405, hallett9@indiana.edu

* This article has a long and winding history — in the language of this paper, it is a "coaster" and each author made essential contributions to the project.

Acknowledgments: This project was made possible through the generosity of the Indiana University Institute for Advanced Study. We thank the anonymous reviewers and editors of the American Sociological Review for their comments and support. We also thank Hyeyoung Kwon, Beth Bechky, Nahoko Kameo, Emily Meanwell, Brian Steensland, Fabio Rojas, Sean Bock, Clem Brooks, Tom Gieryn, Freda Lynn, Terry McDonnell, Meri Dodevska, and Julia Bauer for their comments and assistance. We thank Moira Marsh for her help with database access. An earlier version of this paper was presented at the Sociology of Culture Regular Session, "The Impact of 'Talk' in Everyday Life," at the American Sociological Association Meetings, Montreal, Canada, August 2017. 


\section{Public Ideas: Their VARIETIES ANd CAReers}

\section{Introduction}

In an era of silo mentalities, public skepticism about science, and the threat of fake news, concerns about the disconnect between the Ivory Tower and the public weigh heavily on the shoulders of social scientists. These concerns have led to multiple calls for greater public engagement throughout the social science disciplines (Hartmann 2017; Isaac 2015; Fullbrook 2006; Burawoy 2005; Calhoun 2004, see also the journal Psychological Science in the Public Interest), and there are a growing number of guidebooks that give practical advice for "going public" (Stein and Daniels 2017; Sternheimer 2017; Badgett 2016). Despite these appeals, we lack empirical research concerning what happens to social science ideas once they become available to the public (Camic, Gross, and Lamont 2011). In this article we turn our sociological gaze onto public social science, and we ask questions that are central to the very possibility of public engagement: How do journalists and other mediators between the academy and the public use social science ideas? How do the various uses of ideas develop over time and shape the public careers of these ideas? How do these processes help us to understand what public ideas are and to identify their various types? We answer these questions by examining social science ideas as they are deployed in media designed for the wider public: newspaper articles, columns, and opinion pieces.

The underappreciated role of newspapers and journalists in the transmission of ideas to the public was highlighted decades ago by Herbert Gans during his ASA Presidential Address:

Today's most significant disseminators of our sociology to the general public are magazine and newspaper journalists who incorporate our work in their stories, occasionally because they judge a sociological study to be newsworthy but increasingly often because they want sociological commentary on and in their stories... These journalists are a crucial resource for us, a veritable disciplinary treasure, and they should be given our full and immediate cooperation. (1989: 9) 
Gans' insight endures, and it holds for social science more generally. Although much has changed with the internet revolution (Schudson 2011), journalists are still important disseminators of social science ideas. Despite considerable efforts by social scientists to package ideas in accessible ways, it is rare for those ideas to be employed in the public. Moreover, once ideas enter the public, social scientists lose control over them (Fassin 2017; Dubois 2017) because the dissemination process depends in large part on journalists and other commentators who mediate the relationship between the academy and the public.

We argue that the promise of public social science rests on an understanding of how social science ideas are put to use by these mediators, how they become public ideas in the process, and how their uses develop over time. We recognize that the study of ideas is valuable in its own right (Santoro and Sapiro 2017), and we further contend that scholarly efforts to engage with the public will benefit from a sociology of public social science.

To build such an approach, we identify seven ideas that are frequently and persistently used by journalists and other mediators in twelve high-circulation and geographically diverse American newspapers. The ideas are: "bell curve" (Herrnstein and Murray 1994), "bowling alone" (Putnam 1995), "culture of fear" (Glassner 1999), "clash of civilizations" (Huntington 1993), "creative class" (Florida 2002), "overworked American" (Schor 1992), and "second shift" (Hochschild 1989). ${ }^{1}$ For each idea we examine a 10-year window, beginning with its initial publication. We resist the siren call to explain the causes and conditions that lead to an idea's public success or failure. It is exceptionally difficult to determine why particular cultural objects — whether television shows (Bielby and Bielby 1994), novels (Childress 2017), pop songs (Askin and Mauskapf 2017), or academic ideas_-"hit" and others do not. Lack of information

\footnotetext{
${ }^{1}$ In what follows we treat these as ideas and not titles, and so we do not capitalize or italicize them. We discuss the selection of ideas and newspapers in the methods section.
} 
on negative cases, multiple interdependent causes, and the role of luck make it nearly impossible to identify a formula for success. At best, scholars can point to the common features of objects that do succeed, post hoc (Askin and Mauskapf 2017). To avoid this temptation, we tie ourselves to the mast and move "downstream" (Gieryn 1999: ix). Instead of trying to explain why particular ideas succeed, we study what happens after ideas emerge in the public, and we delve into their referential afterlives (Goffman 1981; Fine and McDonnell 2007).

We find that, as they appear in news stories, ideas are used in two general ways. In one stream the ideas are the cultural object of interest; that is, the ideas are the news. In another stream the ideas are the interpretants for other cultural objects; that is, they are used to make sense of the news. As they ebb and flow between these two streams they exhibit different periods of attention, decline, and revival. These periods unfold in different ways, not as a progression through stages, but as a career (Blumer 1971).

Accordingly, we make three contributions. First, we advance a pragmatic, cultural approach to understanding public ideas, one that emphasizes use and active fit-making by journalists and like mediators. We introduce the concept of applicative flexibility to capture how ideas are applied to new, additional, or different events in order to make sense of those events. As ideas are being deployed as sense-making devices, they are flexible-enough-in-use to be applied to major news events, be applied to more local or mundane events or phenomena, and to be elastically shaped to make unexpected connections to matters of public interest.

Second, we define public ideas. Social science ideas become public ideas when mediators (a) use them as an object of interest (being the news), (b) use them as an interpretant (making sense of the news), and (c) the ideas are used as objects and interpretants in a variety of ways as part of an unfolding career. This definition opens new avenues of research on public 
social science by demarcating public ideas from potential ones and partial hits - those that are fresh on the scene, lack careers, or are used as objects but not interpretants.

Third, we construct a typology of public ideas. While all seven ideas in our sample fit the above definition, there are patterned variations in how they are used and in the shapes of their

careers. These variations yield a typology with three usage patterns ("object heavy," "balanced," “interpretant heavy"), and three career patterns ("splashers," "coasters," "risers"). The typology allows us to conceptualize different types of public ideas, types that span our sample but also go beyond them. Combined, the existing data and the typology provide a theoretical and empirical guide for future research, and a set of propositions to be explored.

To develop our pragmatic understanding of public ideas in use, we draw from research on cultural power (Schudson 1989; McDonnell et al. 2017), cultural objects (Griswold 2004), and the sociology of ideas and thinkers (Lamont 1987; Santoro and Sapiro 2017). After reviewing these literatures, we discuss our methodology, including the selection of ideas and the iterative process through which we examined them in the same newspapers over time. To present our findings we begin with a brief reflection on the initial public appearances of these ideas, and then we present our primary analysis. We use qualitative data to unpack how the ideas are put to use as both objects and interpretants and to identify the processes through which this occurs. Next, we quantitatively chart and compare the careers of the ideas in our sample. This culminates in a typology of public ideas that provides an architecture for a sociology of public social science.

\section{Cultural Power, Cultural Objects, and Fit-Making Processes}

To think about public ideas, we draw from three related literatures: research on cultural power (Schudson 1989; McDonnell, Bail, and Tavory 2017; Childress 2017), research on cultural objects and how different groups construct them (Griswold 2004), and research on 
academic ideas and thinkers that emphasizes the "fit" or "articulation" between ideas and the broader social context (Lamont 1987; Wuthnow 1989). We extend these literatures to consider the processes through which social science ideas are put to use by journalists and like mediators, ${ }^{2}$ how ideas operate as cultural objects, and the reception of social science ideas in news stories. We begin with new research that critically revisits Schudson's (1989) theory of "how culture works" and redirects it away from its original focus on social conditions and towards a consideration of pragmatic social processes. In theorizing the efficacy of culture, Schudson (1989: 59) argues that some cultural objects or symbols (in our case social science ideas) have “cultural power," defined as "the capacity for an object to affect belief and behavior" (McDonnell 2010: 1804). To conceptualize where cultural power comes from, Schudson emphasizes "the conditions — both of the cultural object and its environment — that are likely to make the cultural object work more or less" (Schudson 1989: 160). One key condition is "resonance," the extent to which an object fits "with the life of the audience" (1989: 167). In this view, a social science idea would have "resonance" with the public to the extent that it fits their worldview, experiences, and expectations.

Although this pairing of cultural power and resonance seems intuitive, it is prone to circular reasoning: an object is resonant because it fits, but it fits because it is resonant (McDonnell, Bail, and Tavory 2017: 2; Bail 2015; Berbrier 1998). Circular reasoning also undermines Schudson's condition of "retrievability," where the power of an object hinges on its availability in the public: an object is in the public because it is retrievable, but it is retrievable because it is in the public (McDonnell, Jonason, Christoffersen 2017: 2).

\footnotetext{
2 We use the term "mediators" in a general way and not in the specific way found in Actor Network Theory (ANT). In ANT, in linking actors, "mediators" transform entities and relationships, whereas "intermediaries" link but to not transform (Latour 2005). The journalists and commentators in our study combine elements of both.
} 
These are critical problems, but instead of dismissing Schudson's insights, McDonnell and his colleagues (2017) salvage them by shifting the focus to treat resonance as an emergent process. Drawing from pragmatism (Peirce 1991; Tavory and Timmermans 2014), they conceptualize resonance as an experience that develops as people act to "puzzle out, or 'solve,' practical situations" (McDonnell, Bail, Tavory 2017: 3). With this, resonance is less of a causal condition and more of an "Aha" moment that occurs when people resolve issues and see things in a new light (2017: 4). As McDonnell et al. note, there are any number of things that might plausibly "fit" some requisite condition, but they only become resonant when put to use. Thus, a social science idea is not resonant simply because it fits an existing cultural condition. Rather, an idea gains resonance when it is put to use to make sense of some problematic situation.

Expanding this work, we likewise shift from a focus on "retrievability" as a condition to retrievals as a fit-making process. We conceptualize retrieval as a process in which people actively draw ideas from a cultural archive (Griswold 1986: 188) ${ }^{3}$ to help make sense of their world. During this process ideas can be retrieved both as an object of interest (being the news), and as an interpretant to understand some other cultural object (making sense of the news). In this way, retrieval and resonance processes can be interwoven. As actors puzzle through events (in our case news events), they do not do so in a vacuum. Instead, they retrieve ideas as possible sense-making devices in an attempt to interpret situations and solve their practical problems, creating the kind of resonance that McDonnell and his colleagues identify. Moreover, each time this process of retrieval and fit-making occurs, the ideas regain resonance and remain available for future retrieval. However much an idea might have the potential to "fit" with the social context, if it is to be resonant with the public, it must still be retrieved by actors and put to use

\footnotetext{
${ }^{3}$ This could be described as a "cultural tool kit" (Swidler 1986) "repertoire" (Lamont 1992) or even "collective memory" (Halbwachs 1992), but since written documents provide the grist for this paper we use "archive."
} 
through this kind of pragmatic fit-making process. Moreover, it is through this process that ideas come to have a career - a record beyond the first public appearance.

To gain further insight into these processes, we draw from the more general line of research on "cultural objects." In many ways, social science ideas are cultural objects, what Griswold (1987; 2004) defines as shared meaning(s) embodied in form. The meanings that come to define cultural objects necessarily exist as part of a social relationship, because "cultural objects live only insofar as they are experienced by human beings" (Griswold 1986: 187). With this, research on cultural objects eschews an intrinsic view of meaning and examines how audiences receive and respond to objects (DeVault 1990). Seen in this relational light, an important part of fit-making is interpretive flexibility: the polysemous manner in which the same cultural object is infused with a variety of meanings by different audiences (Pinch and Bijker 1987; Bijker 1995). ${ }^{4}$ Interpretive flexibility is a constructivist concept, but it has limits. Cultural objects are multivocal, but not omnivocal (Griswold 1987). They are the medium of responses, but only rarely do they generate a homogeneous response (Childress and Friedkin 2012: 64). ${ }^{5}$

The dynamics of interpretive flexibility are evident in the research on the reception of cultural objects (although this literature does not always use the term "interpretive flexibility"). These studies examine a broad range of objects, from movies (Shively 1992) to music (Binder 1993) to art (Beisel 1993) to literature (Santana-Acuna 2014), but they all show how the same object can be variously interpreted to fit different social experiences (Childress 2017). We extend this work to consider the reception of social science ideas in news stories. Based on the

\footnotetext{
${ }^{4}$ The idea of interpretive flexibility originates from science and technology studies, a literature with many affinities with cultural sociology. For a discussion see Epstein (2008) and Griswold, Mangione, and McDonnell (2013).

${ }^{5}$ Cultural objects also vary in their capacity to be interpreted in different ways. For example, the purposefully ambiguous features of the Vietnam Veterans Memorial enable it to be infused with very different and sometimes competing meanings, but this is unique among American war memorials (Wagner-Pacifici and Schwartz 1991).
} 
data we introduce a related concept: "applicative flexibility." In the case of applicative flexibility, it is not so much that the meaning of an idea changes or becomes polysemous (as with interpretive flexibility); rather, the idea is applied to a new, additional, or different event (a different cultural object) to give meaning to that event. We find that, as ideas are being deployed as sense-making devices, they are flexible-enough-in use to be (1) applied to major news events, (2) applied to more local or mundane events or phenomena, and (3) elastically shaped to make unexpected connections to matters of public interest.

Finally, we draw from the small but vibrant line of research on academic ideas and thinkers (McLaughlin 1998; Camic and Gross 2001; Mizruchi and Fein 1999). This research examines the "social life of ideas" (Santoro and Sapiro 2017), and, as with the research on cultural objects, these studies emphasize a relational context. As Lamont argues, "The legitimation of theories results more from a complex environmental interplay than from the intrinsic qualities of the theories themselves" (1987: 614-615). Key here is what Lamont calls "fit," or what Wuthnow (1989: 3) calls the "problem of articulation:" ideas must be compatible enough to their social settings so as to be recognizable and relevant, but they must also have an element of novelty that distinguishes them from accepted thought.

This research also examines the active fit-making efforts of the authors, including how authors package ideas and adapt them to multiple contexts (Lamont 1987), how they selectively acknowledge their predecessors to appeal to contemporaries (Camic 1992), and how they engage in intellectual performativity (Bartmanski 2012; Alexander 2011: 195-203). We share this interest in ideas and active processes of fit-making, but instead of focusing on the scholarly context and the efforts of academic authors, we focus on journalists and other mediators who 
write newspaper articles, columns, and opinion pieces. As Gans (1989) noted, these mediators have a central role in bringing social science ideas into the public.

\section{The Study: ReSearch Design, Methods, AND Analysis}

To study public ideas — what they are, how they are put to use, and how they developwe examine seven social science ideas as they appeared in twelve high-circulation newspapers. To select ideas, we created a preliminary long-list of possible candidates: we consulted bestseller lists, solicited suggestions from colleagues, and utilized previous research on social science bestsellers (Longhofer, Golden, and Baiocchi 2010; Gans 1998). Since we are interested in how social science ideas become public ideas, we restricted our search to ideas authored by social scientists. ${ }^{6}$ We also restricted our search to ideas published for at least 10 years because we are interested in use over time. Additionally, ideas had to be searchable in electronic databases. ${ }^{7}$

Next, we compared the Google citations for the ideas on our long list with the number of mentions or "hits" they received in our newspaper sample over 10 years (as we explain shortly). Table 1 provides a partial visualization of this process, with information about sales when available. ${ }^{8}$ As the table suggests, there is no direct connection between citations, sales, and hits in our newspaper sample. Unequal Childhoods (Lareau 2003), for example, has 4,632 Google citations and high sales, but only 11 hits in our newspaper sample. This demonstrates the possible disconnect between the popularity of an idea in the scholastic and public arenas, and

\footnotetext{
${ }^{6}$ Although figures such as Malcolm Gladwell introduce ideas into the public, to do so they draw from and mediate social science ideas. In this, they are closer to the journalists and commentators who use social science ideas in news stories than they are to social scientists. Indeed, Gladwell is a journalist.

${ }^{7}$ Unfortunately, the electronic necessity creates a historic restriction that excludes famous ideas such as "lonely crowd" (Riesman 1950), "meritocracy" (Young 1958), "presentation of self” (Goffman 1959), "exit, voice, and loyalty" (Hirschmann 1970) and even "Managed Heart" (Hochschild 1983), among others.

${ }^{8}$ Sales numbers are exceptionally difficult to find because publishers guard this information closely (Longhofer, Golden, and Baiocchi 2010, Gans 1998). The reported numbers are from Longhofer, Golden, and Baiocchi (2010).
} 
shows that high sales do not necessarily correspond to significant public use. Table 1 also underscores how exceptional it is for a scholarly idea to become a public one.

\section{-----TABLE 1 HERE-----}

We reiterate that Table 1 provides a partial listing of our search. From the long-list, a logical cut-point of fifty hits emerged, with a large gap between second shift ( 88 hits) and when work disappears (37 hits) (Table 1). Using this approach, we selected "bell curve," "bowling alone," "creative class," "clash of civilizations," "overworked American," "culture of fear," and "second shift" for analysis. Perhaps not coincidentally, the full titles of these works include the very ideas that they advance. ${ }^{9}$ In other words, the abbreviated titles are ideas: they are loose sense-making devices for understanding a phenomenon.

In most cases the emergence of the idea coincided with a book publication, e.g., The Overworked American: The Unexpected Decline of Leisure (Schor 1992). To distinguish the idea from the full book title, we used two strategies. First, when searching our newspaper database, our search terms contained only the idea, the author's last name, and the 10-year period following the initial publication. Including the author's last name is a logistical necessity, otherwise the searches produce masses of unrelated material. ${ }^{10}$ Continuing with the above example, the search consisted of "overworked American," "Schor," and "January 01, 1992 to December 31, 2001." The second strategy was to identify the time period when the idea

\footnotetext{
${ }^{9}$ It seems telling that, with the exception of "Code of the Street," "Distinction," and the subtitle to "Heat Wave" ("Social Autopsy"), the titles of the books on the second half of Table 1 do not encapsulate ideas. Searching for the associated ideas or additional ideas does not change the overall results. For example, a search for "Lareau" and "concerted cultivation" yields one hit. "Bourdieu" and "cultural capital" does not yield new hits.

${ }^{10}$ For example, searching for "bowling alone" without "Putman" yields unrelated articles about professional bowling. Searching for "cultural capital" without "Bourdieu" yields unrelated articles that describe various cities as the "cultural capital" of a state, region, or country. We acknowledge that the logistical need to include the author, as well as the historical frame imposed by searchable electronic databases, means that we are unable to study important ideas such as "hegemony" and "self-fulfilling prophecy," ideas that are so successful that they are used in the public without any scholarly reference.
} 
emerged. For example, in the case of "bowling alone," Putnam published his book in 2000, but the idea was first published in an academic article in Journal of Democracy in 1995. Here, the search spanned "January 01, 1995 to December 31, 2004."

To create a stable search framework across all seven ideas, we developed a theoretical sampling of the most widely circulating newspapers in the U.S. Following Benediktsson (2010), we obtained circulation data using the Audit Bureau of Circulations (ABC) and the Standard Rate and Data Service (SRDS). We compared the 2011 versions of these lists and restricted our search to newspapers that appeared in the top fifteen for circulation on both lists, yielding twelve newspapers: Atlanta Journal-Constitution, Chicago Tribune, Dallas Morning News, Denver Post, Los Angeles Times, New York Times, Newsday, Philadelphia Inquirer, Minneapolis Star Tribune, USA Today, Wall Street Journal, and Washington Post. ${ }^{11}$ This sample exhibits a geographical spread across major cities in the Southern, Midwestern, Western, Eastern, and Northern regions of the U.S. However, since it excludes lower-circulating regional newspapers, this sample may exhibit an urban bias. It also excludes internet news outlets that have gained prominence since 2005 but do not coincide with the 10-year windows for the seven ideas. It is worth noting, however, that all of the newspapers have online instantiations, and print articles typically appear online with the same or similar content. While there is some variation in the political leanings of the editorial boards, the newspapers are all established, mainstream outlets.

We conducted our searches across the newspapers using ProQuest and Access World News, two online databases that allow for a stable sampling frame. Table 2 provides a summary of the search results from two types of searches: "standard" and "full-text." "Standard" searches

\footnotetext{
${ }^{11}$ The $\mathrm{ABC}$ and the SRDS are widely used among advertising agencies to assess newspaper circulation. Houston Chronicle also appears on both lists, but we had to exclude it because it is not available in databases for the full span of our study. We used the 2011 list since the latest idea in our sample, "creative class," was published in 2002.
} 
may not return full-text articles; sometimes only brief abstracts or titles are retrieved. Standard results were used to determine which ideas to include in our analysis (over the threshold of 50 hits). "Full text" searches yield complete articles or extended abstracts that have enough detail to be analyzed qualitatively (if the abstract included the reference to the idea and surrounding text). ${ }^{12}$ We used the full-text and extended abstract results to code the articles and examine how the ideas were being used in the public, and to chart the quantitative hits for each idea over time.

\section{-----TABLE 2 HERE-----}

Data analysis unfolded through multiple, iterative stages. Since we are interested in how social science ideas are put to use by and in the public, we began with an inductive, interpretive approach with an emphasis on human coding instead of quantitative techniques such as topic modeling. In this phase we manually coded the qualitative content of the 1121 full text/extended abstract news stories. Initial codes were generated by a pilot project focusing on "bowling alone," and new codes were developed through an ongoing conversation between the data and related literatures (Ragin 1994). To increase reliability, the second author completed the coding with occasional help from another research assistant. This pairing allowed us to conduct interrater reliability checks on the coding without undue confirmation bias from the first two authors.

Multiple codes were developed, and as we worked to understand the data, codes that focused on the "usage" of the ideas in the news stories were especially revealing. The "usage" code changed as our understanding of the data changed, but across the phases of coding and recoding inter-rater reliability scores were high, with a Kappa $>.70(\mathrm{~K}=0.84)$ on the low end and a Kappa >.70 $(\mathrm{K}=0.94)$ on the high end. Through this process we came to focus on ideas being used as "objects" (being the news) and "interpretants" (making sense of the news), with a much

\footnotetext{
${ }^{12}$ Extended Abstracts were used for one newspaper: The Atlanta Journal Constitution for any articles pre-2001.
} 
smaller, third category of use as a "credibility signal" (used to boost the credibility of a news story without discussion or analysis of the idea itself). It was through further examination of the "interpretant" code that we came to identify and understand the three aspects of applicative flexibility (to make sense of major news events, to make sense of more local news or mundane phenomena, to create unexpected connections to matters of public interest). For further discussion of the coding process, see Online Appendix A.

We used Microsoft Word and Excel to manually code the articles, creating spreadsheets as well as text. Using excel enabled us to move into a quantitative phase, numerically charting hits over a 10-year span for each idea, as well as usage (object, interpretant, credibility signal) over time. This approach allowed us to diagram and compare the careers of the seven ideas, and facilitated the creation of a typology of public ideas.

In what follows we begin with a brief discussion of the initial hits in the public, before moving into the main substance of our analysis (for summary capsules of each idea, see Online Appendix B). Our presentation parallels our methodological process, starting with a qualitative analysis of how the ideas are used in news stories as objects (being the news) and as interpretants (making sense of the news) with applicative flexibility. This is followed by a quantitative analysis of the ideas and their specific careers over time, and the typology of public ideas.

\section{REFLECTIONS ON THE INITIAL HITS}

The initial instances of media attention for an idea — or its "hits"-are important because

they place the idea in a cultural archive for later acts of retrieval: An idea cannot have a career if it does not make it into the public. These hits are a starting point and merit some attention. However, any effort to explain why some ideas gain public attention and others do not would require data on negative cases that are difficult to identify; we select on the dependent variable as 
a practical necessity. At best we can cautiously describe some of the commonalities and features of the ideas. Our data and the existing literature suggest a complex "coincidence of factors" (Baumann 2001: 420) that are possibly necessary but hardly sufficient for making an initial hit. First, there are similarities in the characteristics of the authors, the publishers, and their related networks. Table 3 provides basic information on the institutional affiliations of the authors at the time of publication and their publishing houses. The seven ideas were all published in trade presses, indicating lay readability and suggesting that the ideas had already gone through a popularization phase during the editorial process (Hilgartner 1990). All seven authors benefitted from the "halo effect provided by elite universities" (McLaughlin 1998: 219). Some "halos" are bigger than others, but they are all beneficial in this competitive opportunity space (Baumann 2001). The authors, as well as the journalists who serve as mediators, have advantageous positions in the stratified field of cultural production (Bourdieu 1993; Benson and Neveu 2005). This field likewise encompasses the network of editors, agents, and publicists that animate the book publishing industry and who market the ideas across multiple media platforms (Coser, Kadushin, and Powell 1982; Greco 1997; Epstein 2001). Through these elite networks the ideas become available to a broad range of "operatives" (Hilgartner and Bosk 1988) including symbolic “entrepreneurs" (DiMaggio 1982; Fine 1996), "promoters" (Molotch and Lester 1974), advocates, and the like. For example, early on "bowling alone" caught the attention of George Will, who wrote an op-ed about it in Newsday (01/05/1995). Likewise, "creative class" became central to John Hickenlooper's policy platform when he ran for Mayor of Denver, appearing in the Denver Post's campaign reports. 
Second, there are a number of relevant cultural and contextual conditions. Timelinesswhere the initial publication is coincident with a big event — can matter and is difficult to orchestrate. For example, by happenstance the publication of "culture of fear" coincided with the shootings at Columbine High School and it was used to reflect on the event. These seven ideas also invoke "conditional universals" that "remind readers about the existence of a historical context inside of which new generations of actors and organizations can agree that the contents of [a work] are 'universal."' (Santana-Acuna 2014: 100). Themes such as race and poverty (bell curve), tensions between the individual and the community (bowling alone), powerful emotions (culture of fear), global conflict (clash of civilizations), urban blight and renewal (creative class), and the tensions between work and leisure (overworked American) and work, gender, and family (second shift), all reflect "broad human conditions and contradictions which, if not actually universal, are at least recurrent in Western thought" (Griswold 1986: 205).

The features of the ideas themselves can also matter, particularly in how they embody these "deep mythic themes" (Hilgartner and Bosk 1988). These themes are familiar to readers and reflect known genres (Lena 2012; Lena and Peterson 2008), but the couplets of the ideas, e.g., "bowling" vs "alone" and "civilization" vs "clash" are contrarian, signaling both similarity and differentiation (Askin and Mauskapf 2017). Controversy in this regard can also be useful. For example, while the initial media responses to "bell curve" and, to a lesser degree, "clash of civilizations" were negative, the criticism created attention. This also suggests that the ideological content of the ideas, and how they articulate and disarticulate with the ideologies of mediators and public audiences (Wuthnow 1989), has a role in getting ideas on the public map.

These kinds of conditions are probably necessary but not sufficient for ideas to make it into the public. It is easy to think of examples that meet many if not all of these criteria but do 
not have broad and enduring public success (Unequal Childhoods, Making Ends Meet, Code of the Street). In a real way, "all hits are flukes" (Bielby and Bielby 1994). Instead of trying to explain why some ideas hit, we focus on how the ideas are put to use in news stories, and how that use develops over time. In particular, we focus on how ideas are used as objects (being the news), how they are used as interpretants (making sense of the news), and how the fit-making process involves applicative flexibility.

\section{IDEAS AS OBJECTS: BEING THE NEWS}

While the initial hits alone do not make a career, they are important because they put the idea in the cultural archive of the very people likely to retrieve the idea in the future: journalists and other commentators who write newspaper articles, columns, and opinion pieces. During the early stages of their careers, the ideas are often treated as a cultural object of interest. That is, the ideas themselves are the news. One way that this occurs is through the publication of bestseller lists. Although these lists are brief, they continually place the idea in the public. Of more significance are book reviews and opinion pieces that explore the idea as a focal object of interest. Take this opening to a review of Overworked American:

Do you feel that you're losing the rat race-working more and enjoying it less? Then you're a typical American, argues Harvard economist Juliet B. Schor in a provocative new book that's well worth reading, if you can find the time." (Newsday 02/04/1992)

In this kind of article, the idea is front and center. It often appears early in the piece, as with this example:

Attention, canny big-city mayors and ambitious urban planners: Be nice to somebody with a nose ring. Take a painter to lunch. Pick up a software designer's dry cleaning. And make sure your favorite gay person has a nifty skyline view. In other words, nurturing the creative community is a good idea for public officials who want to keep their cities economically competitive - not to mention funky, interesting places to live. Or so says Richard Florida in "The Rise of the Creative Class" (Basic Books). (Chicago Tribune 08/11/2002) 
In both of these examples, the scholarly idea is the news-it is the cultural object of interestalthough it is news that journalists describe as "soft;" of a human interest or social type (Tuchman 1978: 48; Gans 1980: 19).

The ideas may also be treated as objects later in their careers. This can happen when the idea is retrieved in the context of a new, related publication. Take this review of Time Bind:

The Time Bind: When Work Becomes Home and Home Becomes Work. .. Arlie Hochschild, author of The Second Shift, a study of the demands working wives and mothers faced at home, now turns her attention to the ways in which Americans do-or more often don't—balance work and family. (Washington Post 09/14/1997)

Second shift is an object of interest in this passage, one that is related to the new book, and this retrieval of second shift helps to bolster the worth of them both.

Another example of this kind of object-related retrieval process is evident in this review of Murray's later work related to bell curve:

Tautologies will be the chief charges against Charles Murray's Human Accomplishment: The Pursuit of Excellence in the Arts and Sciences, 800 B.C. to1950. . Co-author of the controversial racial education study, The Bell Curve, Dr. Murray set out to assemble humanity's "résumé." It seems we all were applying for a job.

(Dallas Morning News 12/07/2003)

This excerpt has a more critical tone relative to the previous examples, and, as we will see, this was common with bell curve. Nevertheless, through this process, bell curve once again became an object of controversial interest, nearly 10 years after its first appearance in 1994.

This kind of object-related retrieval process is exemplified in the 10-year career of "creative class," which Richard Florida reinforced through the publication of four related books $(2004 ; 2005 ; 2008 ; 2010)$. While Florida's productivity is remarkable, all of the ideas in our sample benefitted from this process (Murray 1997; 2003; Schor 1998; Putnam 2000; Putnam and Feldstein 2003; Huntington 1996; Hochschild 1997; Glassner 2007). In a virtuous cycle, the 
established notoriety (or infamy) of the original idea makes the new publication newsworthy, bringing the original idea back to light and refreshing the cultural archive.

These processes are important, but they are an incomplete part of becoming a robust public idea. At various times in their careers, these ideas are treated not only as objects, but more interestingly, as interpretants for some other cultural object or phenomena. That is, not only are these ideas the news, they are also used and retrieved to make sense of the news.

\section{IDEAS AS INTERPRETANTS: MAKING SENSE OF THE NEWS}

Being an object in the news is an important part of being an idea in the public, but central to the very notion of an "idea" is that it provides an understanding of something else. Being used as an interpretant is central to being a public idea. Being retrieved to make sense of the news is also vital to an elongated career, and it is hard for social scientists or publishers to orchestrate this process because it is beyond their immediate control. Instead, it is a process of fit-making where journalists and other mediators retrieve an idea and stretch it across multiple news events, objects, and phenomena. This process is one of applicative flexibility, in which the meaning of the idea itself does not change; rather, the idea is applied to a new, additional, or different object as a way to make sense of that object. The use of the idea is "flexible" in the sense that it can be used to understand many things. Our data indicate that, as the ideas are being pragmatically deployed, they are flexible-enough-in-use to (1) be applied to major news events, (2) be applied to more local or mundane events or phenomena, and (3) be elastically shaped to make unexpected connections to matters of public interest.

\section{Applicative Flexibility One: Fit-Making to Make Sense of Major News}

One aspect of applicative flexibility occurs when the author of a news story retrieves an idea to create an understanding of "hard" news - a major event of national or international 
significance (Tuchman 1978: 48; Gans 1980: 19). While these major events can be sudden and unexpected, the fit-making process is generally congruent with the intended meaning of the idea - the idea is applied to a new case, but the idea itself does not change.

This process is evident at different points in the careers of all of the ideas in our sample, but it is most dramatic in the case of "clash of civilizations" and terrorism, particularly 9/11. The events of that day presented a horrible new problem that had to be puzzled-through (McDonnell et al. 2017: 3), and many writers retrieved clash to do so. To quote a Washington Post article:

We are at war - some kind of war. The academicians - Samuel Huntington of Harvard comes to mind - would call this a clash of civilizations, a fight not about territory or spoils but over how to look at the world. Some people would kill themselves and take so many others with them just to, to what? We still don't know. We may never know. We are at war, all right, but with whom? (Washington Post 09/12/2001)

In the midst of sudden, painful uncertainty, Huntington's idea seemed to provide an interpretation or at least a guideline for the kinds of questions to ask.

Across the country reporters and commentators retrieved clash and applied it in an effort to create understanding. A week after the attack a Los Angeles Times commentator wrote:

The unspeakable hostility that shouted through the silence Tuesday was so vast that it suggested the United States was facing what historian Samuel Huntington has labeled a "clash of civilizations"--an enmity so fundamental that neither threat nor negotiation, nor any of the tools of modern statecraft, can tame it. Which means that our capacity to eliminate this threat is probably far more limited than we'd like to admit today. (Los Angeles Times 09/17/2001)

As the idea was retrieved to make sense of this major event, it became resonant anew (McDonnell et al. 2017). Indeed, as we will see, it had its most hits in 2001.

This aspect of applicative flexibility is also apparent in the use of culture of fear. Following its publication in 1999, journalists and commentators retrieved culture of fear to provide an understanding of 9/11 and its aftermath, as well as another major event: the 2002 sniper attacks in Washington D.C. For example, while referencing Glassner and discussing 
culture of fear earlier in the article, a Chicago Tribune columnist went on to apply the idea:

American's have long had a macabre obsession with sensational crime, but it may have reached a watershed with the Washington-area sniper attacks. Cable news turned to reporters and commentators for 24-hour coverage, ratings soared and people thousands of miles from Washington told pollsters that they feared sniper attacks. (Chicago Tribune $11 / 11 / 2002)$

This writer used culture of fear to make sense of the tremendous national concern for what could have been viewed as a localized event. With this retrieval process the idea became resonant anew: as we will see, with the exception of its publication in 1999, culture of fear had its highest levels of hits in 2001 and 2002.

Some major events, such as presidential elections, provide recurring opportunities for the creation of cultural meaning (Schudson 1989: 163). The 1992 election was particularly novel, as Hillary Clinton did not fit the traditional model of First Lady, and Dan Quayle bemoaned the conduct of the television character Murphy Brown. In this context, a commentator for the Philadelphia Inquirer retrieved and then applied the idea of the second shift:

For the millions who argue about who should scrub the bathtub or who should make dinner, there will finally be a sympathetic ear in the White House next month. . Hillary Clinton knows what it's like to juggle job, family and home. The big issue for these women is no longer whether to have a career but whose career comes first. . . Arlie Hochschild, a sociologist who detailed the housework arrangements of two-career couples for her book The Second Shift, found that working mothers log an extra month a year in housework and spend an average of four hours less per week at their jobs than their husbands. Those statistics inevitably make women less competitive in the workplace. (Philadelphia Inquirer 12/06/1992)

Second shift provided a heuristic for understanding life as career woman and First Lady. Although this kind of fit-making is compatible with the idea, it involves a fresh application to what was, at the time, a recurring national event with a novel spin. While this process involves some flexing of the original idea — when Hochschild wrote her book in 1989 she was not detailing the lives of First Ladies — it is not too far afield from her original intent. 


\section{Applicative Flexibility Two: Fit-Making with more Local or Mundane Events}

The ideas in our sample were also used to cover and make sense of phenomena that are more local in scope or mundane in implication. This process tends to be congruent with the intended meaning of the idea and the original scholarly work, yet entails application to a broad range of events and phenomena that, if less national or dramatic, are still news.

Take, for example, this retrieval of bowling alone in a Denver Post article about the city's public-transit expansion:

After years of bickering about the merits of building public transit, when the southwest light-rail line opened to commuters this week, the system was overwhelmed with eager riders ... And don't look now, but the trend could produce benefits beyond eased gridlock. In his book "Bowling Alone," Robert Putnam, a Harvard professor of public policy, suggests that reducing the time we spend alone in our cars could be a step toward building better communities. Putnam has assembled a mountain of data to explain why we're such a bunch of stressed-out, crotchety loners. (Denver Post 07/22/2000)

This application is not surprising in as much as Putman discusses commuting in his book, but this additional application stretches the idea across a specific local case to make sense of the "eager riders" who surprisingly "overwhelmed" the new system: "crotchety loners" seeking an escape from gridlock and a means of community.

A similar instance is found in this application of culture of fear to make sense of paranoia about freeway shootings in Los Angeles:

Sociologists said it is easy to understand why the freeway shootings have received so much media coverage: They have occurred in a common space shared by everyone who drives. But this also makes it difficult to put the shootings in some sort of perspective. . . "So if we are hearing about these incidents constantly ... every time we turn on the TV or radio, it's going to be difficult for police to counter with the facts," said USC sociology professor Barry Glassner, author of "The Culture of Fear: Why Americans Are Afraid of the Wrong Things." (Los Angeles Times 05/04/2005)

Given that road rage features prominently in Glassner's book, it is not surprising that culture of fear would be used to make sense of freeway shootings. Our point is that this kind of use shows 
that such an application rests easily within culture of fear's flexible range. The idea can be retrieved and applied anew, creating fresh resonance with every such instance in the city of Los Angeles, even if those events do not qualify as national news.

Another type of application involves objects or events which, if more general than something like L.A. freeway shootings, are mundane. Take the ordinary task of eating lunch:

High noon: time to stumble through the skyway or to the employee cafeteria. Here's a better idea: Get out of the building, get out of your rut, get out of your mindset. Taking a break - a real break - boosts your production, experts say. Eating lunch at your desk is not only bad for you, it may be bad for the job: Juliet B. Schor, author of "The Overworked American" (Basic Books, \$22.95) writes that "for some, shorter hours and schedules can actually raise productivity." Schor cites several cases of corporations that reduced workers' hours only to find sales went up, absenteeism declined and pace, efficiency and morale improved. (Minneapolis Star Tribune 04/29/1992)

Eating is a regular part of a workday, and this article applies overworked American to reconceptualize the quotidian: lunch fuels productivity as well as the body, but only if it entails a genuine break. Lunch breaks are a frequent topic in Schor's research, so while this application does not stretch the idea itself, the capacity for such mundane applications illustrates the flexibility-of-the-idea-in-use, and its position as a public idea.

\section{Applicative Flexibility Three: Elastic Fit-Making to Make Connections to Matters of}

\section{Public Interest}

In the first two components of applicative flexibility, the ideas are spread across qualitatively different events or phenomena (major national or international news vs. more local or mundane). In other words, the flexibility becomes apparent in the type of thing the idea is being applied to. The third component flexes the idea itself through a creative use. Here the fitmaking process is less intuitive compared to the first two kinds of applicative flexibility, and less intuitive given the original focus of the scholarly research. Although the meaning of the idea itself does not change, it is flexed to create an unexpected connection. 
This third aspect of applicative flexibility is especially evident in the career of bowling alone. Take this example, where a commentator for the New York Times retrieved the idea and applied it to make sense of the widespread popularity of noise-canceling headphones:

"Its success surprised even us," Ms. Cinotti [a company spokeswoman] said. Most people use headphones on flights, but, increasingly, they are used to block out the neighbor's lawn mowers, colleagues' chatter, fellow commuters' irritability, or to sleep and meditate. But do these filters create an alienable world, one too cushioned, too impermeable to surprise? ... Ms. Smith [a psychotherapist] worries that all of this will become the ultimate form of what social scientist Robert Putnam famously called "bowling alone." Look, she said, at the decline in participation in things like the traditional New England town meeting. "A democracy rests on everybody feeling that they have a stake in being part of a conversation," she said. "In running into our bubbles we are abdicating our more public roles in a way that turns the public realm over to people who may not have our interests at heart." (New York Times 03/21/2004)

The most intuitive and parsimonious explanation for the success of noise canceling headphones is that contemporary life is too loud, and it is a stretch to go from headphones to the decline of democracy, but this commentator nonetheless retrieves bowling alone to make this connection and interpret its implications for society.

This elastic fit-making process is also apparent in this article on the popularity of garage bands in Atlanta:

There are no rock stars in this room, just dads, husbands, businessmen — guys with big chunks of their lives disappearing in the rearview mirror. . . And perhaps they are a part of the vanguard in a new realm of male bonding called band practice ... Robert Putman observed in "Bowling Alone" that while bowling is on the rise, participation in bowling leagues dropped by 40 percent from 1980 to 1993. Obviously, men need a place to hang out. And though they don't talk about it much, many men will quietly affirm that the friendship in these musical associations is as important to them as the three-cord boogie. (Atlanta Journal-Constitution 08/25/2002)

It is possible to think about garage bands in many ways - the joy of music being the most intuitive — but this author retrieves bowling alone specifically, and uses it to bring blurry themes about middle-age yearning and male bonding into focus via a community lens. In the process the idea is creatively flexed to provide an interpretation for a case that is not an obvious fit. 
Bowling alone was not the only idea to exhibit this kind of applicative flexibility in use.

Take this article that uses creative class to interpret trends towards casual living, and going barefoot in particular:

Being barefoot is symbolic to a great degree of the informality in our society. The person who hit the nail on the head is Richard Florida in The Rise of the Creative Class. With creative people, you get a certain amount of latitude, and it gets expressed in how we dress and how we live. (USA Today 10/06/2006)

Tolerance towards naked feet was never a part of Florida's measurements of urban tolerance, but this writer still retrieves the idea of the creative class to understand this new "latitude."

Applicative flexibility in this third form can be surprising. Take this news story from the Wall Street Journal, discussing the controversy over President Clinton's nomination of Henry Foster-who was found to have performed abortions - for Surgeon General. After criticizing both sides for a lack of civility and charity, the commentary makes an unexpected connection:

For underlying the White House mistakes on the Foster nomination is one unthinking assumption: that anyone with anti-abortion views is not serious, and can be safely ignored. It never occurred to the staffers who examined Dr. Foster's record that anyone might wonder if he ever performed an abortion. It's not something that ever comes up in their enlightened circles, after all; why should it matter to anyone else? We commend to the White House vetters' attention "The Bell Curve" by Charles Murray and Richard Herrnstein, who have written 800 pages on the subject not of racial differences but of an overeducated "cognitive elite" whose members talk only to one another. (Wall Street Journal 02/17/1995)

To make sense of the controversy the commentators retrieve bell curve and flex the idea to explain the shortsighted thinking that led to the nomination of Dr. Foster in the first place.

As this last example shows, the third form could involve major national news (as with the first form of applicative flexibility), or, as the previous examples suggest, more local or mundane phenomena (as with the second form of applicative flexibility). While there is overlap, what distinguishes the third form of applicative flexibility is less the kind of event it is being applied 
to (as with the first two forms of applicative flexibility) and more the elastic shaping of the idea in the application to make a connection to matters of public interest.

Taken together, the career processes of public ideas are summarized in Figure 1.

\section{-----FIGURE 1 HERE-----}

First, through a coincidence of factors, an idea has its initial hits in the public. Moving downstream, we focus on what happens next. Once an idea exists in the public it is available for use by the various mediators who write news stories. Then, in one stream journalists and other mediators comment on the idea primarily as an object of interest. In this stream the idea is the news. The newsworthiness of the idea is further advanced by object related retrievals, for example when another book is written that is related to the original idea. Each time an idea is used as an object or an object related retrieval, it loops back to refresh the cultural archive, keeping the idea in the public and extending its career.

In another stream, journalists and other commentators serve as mediators, and they use the idea as an interpretant. As the ideas are being pragmatically deployed, they are flexibleenough-in-use to (1) be applied to major news events, (2) be applied to more local or mundane phenomena, and (3) be elastically shaped to create unexpected connections. With these three components of applicative flexibility they are used to make sense of the news, and they become public ideas. Via these retrieval processes the ideas become resonant anew. This also serves to refresh the cultural archive, looping back to keep the idea in the public and extending its career.

\section{Public Ideas: VARIETIES ANd CAREers}

Thus far we have demonstrated how journalists and other mediators retrieve social science ideas and put them to use in two main ways, as objects and interpretants. We argue that use as objects and interpretants are two defining features of public ideas, and the third defining 
feature of a public idea is an ebbing and flowing between these uses in an unfolding career.

Before detailing these careers, we present aggregate, quantitative data based on our qualitative coding for how all of the ideas are used in the 1121 articles that we coded (See Figure 2).

An examination of our full sample of articles shows that the social science idea was treated as the object of interest in 412 of them (36.75\%). More often, in 580 articles (51.74\%), the idea was used as an interpretant. In the remaining 129 articles (11.51\%), the idea was used as a type of credibility signal — as window dressing to bolster a news story without discussion or analysis of the idea. In other words, more than $88 \%$ of the articles used the ideas in a meaningful way, either as an object (being the news) or as an interpretant (making sense of the news).

-----FIGURE 2 HERE-----

We developed these categories inductively while reading the qualitative data, which then formed the basis of our coding. ${ }^{13}$ This generality, however, masks the interesting processes that are evident in the preceding section and raises additional questions. How does this usage vary between ideas? How does usage vary across the career of an idea? Are there identifiable patterns of idea retrieval and usage? In this section, we quantitatively address these questions, unpack these varieties, and construct a typology of public ideas.

\section{Bell Curve: Splash and Decline, Object Heavy in Use}

The dashed line on Figure 3 charts the bell curve's full text hits over time. We see a career characterized by a large splash followed by a steep decline, but not disappearance. This fits what we might expect: Ideas exist in a competitive space with limited carrying capacity (Baumann 2001; Hilgartner and Bosk 1988). With this, a pattern of splash and decline makes

\footnotetext{
${ }^{13} \mathrm{~A}$ chi-squared test compares our coding with results had the articles been randomly assigned to each category. The outcome of the chi-squared test, $X^{2}=157.4$ [df $=12, \mathrm{p}<.001, \mathrm{~N}=1121$ ], confirms with a high degree of significance that the results for each category are not random.
} 
sense. While bell curve made a big splash and has the greatest volume of hits in our sample (142 in 1994 alone and 305 total), the response to the idea was quite negative throughout. ${ }^{14}$

-----FIGURE 3 HERE-----

As a social science idea, bell curve garnered considerable attention and was a topic of controversy. This is reflected in the coding for how the idea was used, as indicated in the bar graph appearing below the career-hit chart in Figure 3. Especially in the first two years of its career, bell curve was a newsworthy object of interest: The use of bell curve was coded as an “object" 110 times in 1994, and 40 times in 1995. During this time, bell curve was much more of an idea in the public than it was an interpretant. With this, it is tempting to argue that bell curve is not, in fact, a public idea. However, we must not ignore the many times that the writers of news stories did retrieve the idea to interpret some other phenomena or object: 23 times in 1994, and 17 times in 1995. These numbers are not trivial, especially in light of the other ideas in our sample, all of which have considerably fewer overall hits compared to bell curve. As mentions of bell curve declined over time, how it was used also changed, and in 1997, 1998, and 1999, the people writing news stories more often retrieved the idea as an interpretant, although this trend must be viewed with caution because the numbers are small.

In the aggregate, bell curve was used more often as an object ( $57 \%$ of the articles $\mathrm{N}=175$ ) than as an interpretant (24\% N=74) (see Appendix B Figure 13). If we place bell curve into Figure 1 illustrating the career processes of public ideas, it flows more commonly into the "object" side. It fits the definition of a public idea (object, interpretant, career), but it is an object heavy public idea. Notably, it is also the idea that is most often used as a credibility signal in our

\footnotetext{
${ }^{14}$ We coded the "tone" of all the articles in our sample with the following categories: adopt uncritically, tempered use, critical, and neutral. Fifty-one percent of the bell curve articles exhibited a critical tone, by far the highest of any idea (See Appendix B Figure 12).
} 
sample (18\% N=56). Thus, even though bell curve has, by far, the greatest number of overall hits in our sample, as we will see, it is not as robustly used as an interpretant when compared to the other ideas (For further discussion see Appendix B).

\section{Second Shift: Multiple Peaks, Balance in Use}

Of all of the ideas in our sample, second shift has the smallest overall volume of hits, but its career is no less interesting. Instead of a single splash, second shift's career is characterized by multiple peaks and valleys (see the dashed line in Figure 4). After 1989 (23 hits) the idea experienced decline until a rise in 1992 (nine hits), and another spike in 1997 (nine hits).

\section{-----FIGURE 4 HERE-----}

The bar graph portion of Figure 4 indicates that, during its first year, second shift was used more often as an object than an interpretant. However, in its second year it was retrieved more often as an interpretant before dropping and leveling out in 1991. The resurgence in 1992 took place against the backdrop of Hillary Clinton as First Lady and controversy over the fictional television character Murphy Brown, and the idea was retrieved to make sense of these phenomena and the changing roles of women more generally. The usage drops and levels out again before another spike and switch in 1997, reflecting the publication of Hochschild's related book Time Bind. This brought second shift back into the news, but more as a related object than an interpretant. The numbers indicate a rather different career than bell curve even though they both fit the overall definition of a public idea.

In the aggregate, second shift is balanced in use: It was put to use almost equally as an object (48\% $\mathrm{N}=35)$ and as an interpretant (51\% N=37) (Appendix B Figure 14). If we place second shift into Figure 1 illustrating the career processes of public ideas, it fills both sides, 
although it flows between them as it does so. This pattern is a further contrast to the bell curve's object heavy career.

\section{Culture of Fear, Overworked American, and Creative Class: Peaks and Valleys,}

\section{Interpretant Heavy in Use}

Culture of fear is similar to second shift in that its career exhibits peaks and valleys, and in the sense that it is in the low end of our sample in terms of total full text hits (99). Culture of fear made its debut in 1999 with 22 hits, declined sharply in 2000, but then rose to 16 hits in 2001 and peaked again with 17 hits in 2002. It declined from there but stayed in the public imagination until dropping to a single hit in 2008 (See Figure 5).

\section{-----FIGURE 5 HERE-----}

Whereas bell curve and second shift were more often used as an object during their first years, Figure 5 indicates that culture of fear was quickly used as an interpretant, in part (but not entirely) because it was coincident with the shootings at Columbine High School. Culture of fear was used to make sense of both the event and the public's response. In a similar way, in 2001 and 2002, the idea was retrieved to help interpret 9/11 and the sniper attacks in Washington D.C. The idea continued to be used as an interpretant through 2006 before becoming more of an object in 2007, when Glassner published a book with a related theme: The Gospel of Food: Why We Should Stop Worrying and Enjoy what We Eat.

Combining all of the years, culture of fear was put to use as an interpretant nearly $71 \%$ of the time $(\mathrm{N}=70)$. This is the highest percentage of all of the ideas in our sample (although, in terms of sheer number of interpretant hits, bowling alone is the highest). Despite its smaller volume of total hits (99), culture of fear is the most robust public idea in the interpretive sense. It was also used as an object over $26 \%$ of the time $(\mathrm{N}=26)$ (Appendix B Figure 15). Although 
culture of fear exhibits some ebb and flow between interpretant and object, in terms of how it fills the two sides of Figure 1, it is an "interpretant heavy" public idea.

If we were to only look at its hits during its first five years, overworked American's splash and decline would seem similar to bell curve (See Figure 6): Overworked American had a strong debut with 44 hits in 1992, dropping to 10 in 1993 and declining to six in 1996. In contrast to bell curve, it had a career revival from 1997-1999, with 17, 16, and 13 hits.

\section{-----FIGURE 6 HERE-----}

In terms of how overworked American was used, its career looks more like culture of fear. Indeed, while the idea was used as an object, especially during its first year, it was more often used as an interpretant in the subsequent years of its career. The idea benefitted from a public controversy: it was published at a timely moment to defend American culture. In 1992 a number of Japanese politicians publicly questioned the work ethic in the U.S. In this context, overworked American appeared in news stories both as an object of interest and as an interpretant to make sense of the event and to provide a counter argument. Controversy renewed attention in 1997 when Godbey and Robinson published a book criticizing the idea, and Schor published a related book to support her argument, The Overspent American (1998). During this period the idea was used mainly as a counterpoint to interpret the Godbey and Robinson book.

Combining all of the years, overworked American is interpretant heavy in its usage, as nearly $66 \%$ of the news stories $(\mathrm{N}=86)$ used the idea to make sense of some other object or phenomena. Of the seven ideas in our sample, overworked American ranks second in terms of percentage coded as interpretant. The idea was also newsworthy in itself, treated as an object almost $31 \%$ of the time $(\mathrm{N}=40)$. It was also used as a credibility signal around $4 \%$ of the time $(\mathrm{N}=5)$ (Appendix B Figure 16). 
The creative class idea first appeared in 2002 with the publication of Richard Florida's book The Rise of the Creative Class. Its career hit-chart resembles culture of fear, and its usage resembles the pattern for over overworked American (See Figure 7). When the idea first appeared in 2002 it garnered 28 hits, and it was utilized primarily as an interpretant (21 hits). Although its hits declined in the years that followed, it was continually put to use. The idea rose again when Richard Florida published two related books, Cities and the Creative Class (2004) and The Flight of the Creative Class (2005), reaching 28 hits in 2005 and peaking at 31 hits in 2006. These publications helped keep the (already public) idea in the public mind, while appearing as both interpretant and object. After 2006 the hits began to decline, but the pattern of usage remained consistent: in every year it was used more often as an interpretant, although the gap between object and interpretant varies (for further discussion see Appendix B).

\section{-----FIGURE 7 HERE-----}

In the aggregate, creative class was used as an interpretant over $61 \%$ of the time $(\mathrm{N}=108)$. It was treated as an object nearly $30 \%$ of the time $(\mathrm{N}=52)$, and it was used as a credibility signal around 9\% of the time $(\mathrm{N}=16)$ (Appendix B Figure 17). As with culture of fear and overworked American, it is an interpretant heavy public idea.

\section{Clash of Civilizations and Bowling Alone: Late Rise, Interpretant Heavy in Use}

Compared to the previous ideas, the career hit chart for clash of civilizations looks rather different, perhaps because the idea first appeared in article form in the academic journal Foreign Affairs. Its career started more slowly, with seven hits in 1993, declining to a low of four in 1995, but then rising to eight in 1996 and 13 in 1997 before declining. It then spiked dramatically in 2001 with 32 hits (See Figure 8). 
The numbers are small until 2000. When the idea appeared in 1993, it was used mostly as an interpretant to make sense of conflicts in Bosnia and the Middle East, as well as ethnic and religious conflict more generally. When the book came out in 1996, it became a topic of controversy and interest, and the use of the idea switched to become somewhat more of an object. In 1997 the usage switched back towards the interpretant side to understand the Iranian Presidential election, Middle East tensions, terrorism, and religious and cultural conflicts. The dramatic spike in 2001 reflects the events of 9/11, where clash of civilization was retrieved to make sense of the attack and its aftermath, a trend that continued in $2002 .^{15}$

Taken together, clash was used as an interpretant over $61 \%$ of the time $(\mathrm{N}=70)$, as an object over $25 \%$ of the time $(\mathrm{N}=29)$, and as a credibility signal over $13 \%$ of the time $(\mathrm{N}=15)$ (Appendix B Figure 18). In this way, and despite its different pattern of hits, clash is also an interpretant heavy public idea.

As with clash, bowling alone first appeared in the public via an academic article (Journal of Democracy 1995), and its career trajectory is somewhat similar (See Figure 9). It had a modest start with six hits in 1995. Sparked in part by the Presidential Election, in 1996 it rose to 20 hits as it was used to interpret multiple political issues and topics ranging from religion to civility to postmodernism. In 1997 it declined to six hits. Then it spiked to 66 hits when Putman published the book in 2000. Bowling alone declined but had its second most hits (35) in 2001, declining but staying in the public through 2003, and then rising again in 2004.

\section{-----FIGURE 9 HERE-----}

Throughout its career, bowling alone was used as both interpretant and object, but with the exception of 1999 (usage equal), it was used primarily as an interpretant. The peak in 2000

\footnotetext{
15 For comparison, we also charted a 10-year period beginning with the publication of the book (1996-2005, available in Appendix B). In this chart clash of civilizations is still characterized by a late rise following 9/11.
} 
reflects the publication of the book. Of all the years 2000 was the one in which bowling alone was used the most times as an object (24 times), and yet in that same year it was more often utilized as an interpretant (35 times). After some decline through 2003, it rose again in 2004 when it was retrieved, in part, to make sense of a range of issues in the context of the presidential election (for further discussion see Appendix B). ${ }^{16}$

Taken together, bowling alone is interpretant heavy in its usage (over $60 \% \mathrm{~N}=135$ ). Of the seven ideas in our sample, bowling alone ranks fifth in terms of the percentage of its articles coded to the "interpretant" category. However, it has the highest sheer number of news stories that used the idea as an interpretant. In terms of overall exposure and usage, most scholars would hope for their ideas to be used in the public in this way and with such prevalence. In this sense, bowling alone is an exemplar. It was also used as an object nearly $25 \%$ of the time $(\mathrm{N}=55)$, and as a credibility signal nearly $15 \%$ of the time $(\mathrm{N}=33)$ (Appendix B Figure 20).

\section{A Typology of Public Ideas}

The data indicate that social science ideas become public ideas when public mediators (1) use them as an object of interest (being the news), (2) use them as an interpretant (making sense of the news), and (3) use them as both objects and interpretants in different ways and at different times as part of an unfolding career. These criteria define public ideas. While all of the ideas in our sample fit this definition, the variations in hit patterns and usage allows us to create a typology. The typology consists of three career hit patterns and three career usage patterns, yielding a total of nine types (See Table 4).

\section{-----TABLE 4 HERE-----}

\footnotetext{
${ }^{16}$ For comparison, we also charted a 10-year period beginning with the publication of the book (2000-2009, available in Appendix B). In this chart bowling alone has a strong start followed by some decline but continued high volume and multiple peaks and valleys.
} 
Beginning with the career hit patterns, "splashers" are characterized by a large volume of hits in the first year followed by steep decline, but not disappearance. Other ideas are "coasters," not in the sense that they coast along, but rather like a roller coaster with multiple peaks and valleys. "Risers" are characterized by a smaller volume of hits in the first few years, and a peak later in the career. Likewise, there are three usage patterns: an "object heavy" pattern, a "balanced" pattern that is more equal between object and interpretant, and an "interpretant heavy" pattern.

Five of the seven ideas in our sample are found in the interpretant heavy row, either as coasters or risers, suggesting the following proposition for future research:

\section{P1. Most public ideas are interpretant heavy coasters or interpretant heavy risers}

It seems likely that most public ideas will be found in these categories, not only because most of the cases in our sample fit here, but more generally because a vital part of being a public idea is being used to make sense of various phenomena.

Overall, four of the seven ideas are coasters, two are risers, and there is only one splasher-bell curve. Although bell curve is certainly a public idea (object, interpretant, career), it appears to be an anomaly, suggesting the following proposition for future research:

P2. It will be rare for social science ideas that meet the definition of public ideas (object, interpretant, career) to be splashers

This proposition makes sense for two reasons. First, each time an idea is used in any form (object or interpretant), it refreshes the cultural archive and makes it available for later use, increasing the chances of later retrievals and subsequent peaks. Second, a splash and decline leading to disappearance would not entail a career. To have a career an idea must be able to sustain and have multiple peaks and valleys ("coaster") or a later peak ("riser"), and not simply splash and decline. That bell curve did sustain a career likely reflects its enormous magnitude of 
hits in its first two years, a career driven by controversy and even infamy. Such controversy may be a defining characteristic of public ideas that are splashers.

Although bell curve looks to be an anomaly, the category of "object heavy splasher" is theoretically useful. We suspect that this category also describes partial public ideas-ideas that make a splash as an object of interest (being the news), but then disappear:

P3. Social science ideas that appear in the public but do not meet the full definition of public ideas (object, interpretant, career) will resemble object heavy splashers

This category likely describes the bulk of social science ideas that have their moment in the public as newsworthy objects of interest, without becoming full-fledged public ideas including use as an interpretant and a career. That is, their hit charts will look like bell curve but with much less magnitude in the splash and in the duration.

The two "interpretant heavy risers," clash of civilizations and bowling alone, are telling in that they both made their appearance in the public via publication in academic journals, suggesting the following proposition:

P4. Ideas that hit as articles first are more likely to be risers than are ideas that make their initial hits via scholarly monographs

Throughout our sample, books get more attention in the public than do journal articles, even in the case of clash and bowling alone, which both experienced a new rise when published in book form (1996 for clash, 2000 for bowling alone, see Figures 8 and 9). However, although books receive greater attention, as clash and bowling alone show, and given the great number of books that do not make it (see Table 1), initial publication in a book is neither necessary nor sufficient for becoming a public idea. ${ }^{17}$

\footnotetext{
${ }^{17}$ It is tempting to argue that an article followed by book is necessary for a "riser," but clash's peak came in 2001 following 9/11, and not in 1996 following the book publication. It is also tempting to argue that article first is necessary for a riser, but we can imagine a scenario were an initial book is followed by a more successful book.
} 
The typology is also useful for thinking about the empty cells. Of these cells, "object heavy coasters" and "object heavy risers" seem unlikely. This is not to say, however, that they do not exist, and the typology serves as a guide in the search for possible cases. Although there is only one "balanced" case in our sample, second shift is exemplary in that it so clearly illustrates all of the parts of Figure 1. It highlights both the "object" and "interpretant" streams. We suspect that there are other balanced cases outside of our sample waiting to be identified. Take, for example, a "balanced riser." As with the two actual risers in our sample, this would likely occur when a social science idea first appears through publication in an academic journal, followed by later publication in a scholarly monograph, receiving greater public attention and a peak later in the idea's career but distributed evenly as object and interpretant.

As useful as this typology is for conceptualizing public ideas, it is also a guide for future research: all of the propositions, cells, and scenarios—-whether filled by our sample or currently empty — can be examined through future research on a broader range of ideas in a broader range of media. Considerable knowledge can be gained through the search for empirical examples that fit the nine cells, as well as for examples that do not fit and necessitate revisions to the typology. The typology provides an architecture for a sociology of public social science.

\section{Discussion, Limitations, Future Directions}

Before concluding, it is useful to identify the limitations associated with our analytical focus, theoretical approach, and methodological choices, and highlight the opportunities that these limitations reveal for future research. Analytically, we have taken as our focus "how" questions, and not "why" questions. We can define public ideas, identify how they are used, examine the processes through which they develop and have elongated careers, and construct a typology, but we do not have the necessary data to predict why some ideas hit with the public in 
the first place, or why some ideas are more publicly successful than others. While there is variation in our sample of seven ideas, out of necessity we have selected on the dependent variable. We discuss some cross-case similarities and some plausible necessary but not sufficient conditions in a post-hoc manner, but we can offer no formula for becoming a dominant public social scientist.

In developing a pragmatic, cultural approach to public ideas, we acknowledge the conceptual opportunity costs for the theoretical roads we have chosen not to travel. Although we have recognized the importance of ideology (Wuthnow 1989), field positioning (Bourdieu 1993, Benson and Neveu 2005), networks, and the linkages among authors, journalists, editors, agents, and publicists in the publishing industry (see the discussion of the "initial hits"), we have placed them in the background. Ultimately, we see these theoretical inroads as complimentary rather than competing. We have found these approaches to be especially useful for thinking about the initial hits, and they may provide the optimal paths for answering "why" questions about public ideas. Future research can and should foreground these concerns while retaining aspects of the processual, ideas-in-use approach that we develop. Such efforts can lead the way in explaining both the how and the why of public ideas.

To make our study tractable, we focus on social science as they appear in newspapers. The data include material from influential public intellectuals such as Malcolm Gladwell, Thomas Friedman, and David Brooks, but only when they write in our sample of newspapers. We have not included their own books in our analysis because, although they draw extensively from social science, they are not professional social scientists. However, their books and similar works do link the academy and the public. A cursory look at these kinds of publications suggests that they use ideas in the ways we have outlined here--as objects and as interpretants with 
evidence of applicative flexibility-in-use. These works merit rigorous, formal attention and their conformity to our findings is an empirical question to be answered in future research.

Likewise, we identify the importance of journalists and other mediators who bridge the academy and the public, but we do not provide a theory of mediators, as do approaches such as Actor Network Theory (Latour 2005). In addition to journalists, these mediators include editors, policymakers, consultants, and other professionals who engage directly with target publics (Griswold and Wohl 2015). These professionals use social science ideas as they go about their work, and in doing so they make those ideas public. Future research can examine the various ways that these mediators use social science ideas and how those uses resemble, expand, and depart from the understandings developed here.

Methodologically, we recognize that our selection of ideas by prominent social scientists and the sample of establishment, urban newspapers reflects larger structures of power (Swidler and Arditi 1994). We have focused on mainstream newspapers at a particular historical moment: Our sample spans 1989-2011, coinciding with an era of newspaper prominence, but also newspaper decline as a result of the digital revolution (Schudson 2011). Despite this decline, the high circulation rates for newspapers in our sample and their availability in both print and online formats are useful in that they reflect a broad public. They also have methodological virtues: They are searchable and the articles are available for qualitative coding and quantitative charting. There are, of course, other forms of media that act as purveyors of ideas, including popular online outlets such as Politico, Slate, and Vox. All of these outlets were established after 2005. As such they do not correspond completely or equally with the 10 -year windows for the ideas in our study. This is unfortunate, but had we been able to include these outlets, we do not anticipate changes in the overall patterns: They could add volume to the total number of hits for 
each idea, but it seems unlikely that including them would change the career patterns, nor do we expect a change to the typology and its categories. Ultimately these are empirical questions, and future research would do well to analyze material from these outlets, particularly for social science ideas that have emerged since 2006.

Such research should also consider magazines such as The Atlantic, The New Yorker, and The New York Times Magazine. In contrast to the newspapers in our sample, these outlets target a highly educated public with distinct cultural capital, and their comparatively low circulation reflects this targeted audience. Given our emphasis on circulation and broad publics, we have excluded them from this analysis. However, these works are influential in shaping the debates about ideas, particularly in the early stages of a career. With this, we expect that these outlets will tend to treat the ideas as objects to be discussed, and less so as interpretants to be applied, but this too is an empirical question.

Despite these limitations, we provide a foundation for a sociology of public social science and future research on public ideas. This research can use the typology to guide both the search for and understanding of empirical cases, it can interrogate the four propositions outlined in the preceding section, and it can seek answers to the empirical questions posed above. Future work can utilize our findings and concepts and pair them with creative methods and data to identify and examine potential hits, partial hits, and unexpected flops in addition to fully realized public ideas. This research program can draw additional inspiration from recent work in cultural sociology. One approach would be to go small and deep, following a single social science idea from its inception to its academic publication and into its public reception, much like Childress' (2017) exhaustive study of the historical novel Jarrettsville. Another approach would be to go broad and wide, and to use the tools of computer science to analyze big data on social science 
ideas that appear on bestseller lists over time, much like Askin and Mauskapf's (2017) analysis of nearly 27,000 songs on the Billboard Hot 100 charts. A middle approach would be similar to ours, adding cases and relevant media, such as magazines and online news outlets, but also influential blogs, Ted Talks, and more.

We recognize that, in an era of Twitter, Facebook, YouTube, and Google, public ideas may develop in different ways. Promising opportunities loom for research on ideas in this new era. In 2023 Capital in the Twenty-First Century (Piketty 2014) will have been published for a decade, and Piketty is already being examined by sociologists who study intellectuals (Brissaud and Chahsiche 2017). In 2023 On the Run (Goffman 2014) will have been published for a decade. In 2025 Evicted (Desmond 2016) will reach that mark. Grit (Duckworth 2016) is another potential candidate. ${ }^{18}$ Will they meet the definition of a public idea? Will they have elongated careers? Will they splash and fade, coast, or rise? Will their use in the public be object heavy, balanced, interpretant heavy, or something else? Additional books and ideas will come and go, and research on them can ask these and other questions, while drawing from a broader range of media. Research that addresses these questions may reveal new and different dynamics, and it will go far in establishing a sociology of public social science.

\section{CONCLUSION}

Calls for public engagement are increasingly common in the social sciences. In our own discipline of sociology these calls have been the focus of two American Sociological Association meetings and corresponding Presidential Addresses (Gans 1989; Burawoy 2005). Other disciplines have witnessed similar moments. There is no shortage of social scientists who want to engage with the public, and the Ivory Tower metaphor obscures the many scholars who work,

\footnotetext{
${ }^{18}$ Although Duckworth initially published the "grit" idea in a 2007 academic journal article, it did not start getting public attention in our newspaper sample until 2013, when Duckworth won a MacArthur Genius Fellowship.
} 
often tirelessly, to bring their ideas to the public. These efforts have been only partially successful. Despite extensive toil and attempts to package scholarly ideas in accessible ways, it is uncommon for social science ideas to become public ideas.

In this article we shift the focus. Instead of making additional calls for public social science, debating its merits, or attempting to produce more of it, we instead address questions that strike at the core of the endeavor: How do journalists and other mediators between the academy and the public use social science ideas? How do the various uses of ideas develop over time and shape the public careers of these ideas? How do these processes help us to understand what public ideas are and to identify their various types? In answering these questions, we make the case for a sociology of public social science. We recognize that the study of ideas is valuable in and of itself, and we argue further that scholarly efforts to engage with the public will benefit from research that examines, empirically, how social science ideas become public ideas.

Our approach draws from the concepts and methods of cultural sociology and the sociology of ideas. We elaborate theories of cultural resonance (McDonnell et al. 2017) by focusing not on "retrievability" as a condition, but on retrievals as an active process. We expand research on cultural objects and interpretive flexibility (Griswold 2004, Bijker 1995) by adding the concept of applicative flexibility. In shifting from conditions to process, we resolve some of the problems of circular reasoning that undermine the otherwise valuable research on cultural power (Schudson 1989). Regardless of whether an idea is a potential fit with social conditions, public actors must nevertheless retrieve the idea and connect it to a problem, a process that is observable in how journalists and other mediators utilize social science ideas in news stories.

Empirically, we identify seven scholarly ideas that are frequently and persistently used in twelve high-circulation and geographically diverse American newspapers. For each idea we 
focus on a 10-year window, beginning with its initial publication. Through a careful qualitative and quantitative content analysis of the articles, we make three contributions. First, we advance a pragmatic, cultural approach to understanding public ideas, one that emphasizes active fitmaking by journalists and other mediators who write news stories (Figure 1). Second, we define public ideas. Social science ideas become public ideas when (a) mediators use them as an object of interest (being the news), (b) mediators use them as an interpretant (making sense of the news), and (c) the ideas are used as objects and interpretants in different ways and in different times as part of an unfolding career. Third, we construct a typology of public ideas. While all of the ideas in our sample fit the above definition, there are patterned variations in how they are used and in the shapes of their careers. This allows us to conceptualize different types of public ideas and to develop a research agenda, including propositions to be explored and additional questions to be examined in future studies.

We call for more research on public ideas because the stakes are high. The quest to understand public ideas is a quest to understand the mission and relevance of scholarly activities. In an era in which academia is under attack and public skepticism about social science is high, public ideas gain even greater import. As scholars, do we want our opinions to be heard, do we want our ideas to be newsworthy objects of interest, or do we want our ideas to be used to make sense of the world? The answer, of course, is all of these, and more. In every instance, it is worth understanding how social science ideas are put to use in the public, the processes through which they develop over time, their varieties and careers. 


\section{REFERENCES}

Anderson, Elijah. 1999. Code of the Street: Decency, Violence and the Moral Life of the Inner City. New York, NY: W.W. Norton and Company.

Alexander, Jeffrey C. 2011. Performance and Power. Cambridge, UK: Polity Press.

Askin, Noah, and Michael Mauskapf. 2017. "What Makes Popular Culture Popular? Product Features and Optimal Differentiation in Music." American Sociological Review Online First.

Badgett, M.V. Lee. 2016. The Public Professor: How to Use Your Research to Change the World. New York, NY: New York University Press.

Bail, Christopher. 2015. Terrified: How Anti-Muslim Fringe Organizations Became Mainstream. Princeton, NJ: Princeton University Press.

Bartmanski, Dominik. 2012. "How to become an Iconic Social Thinker: The Intellectual Pursuits of Malinowski and Foucault.” European Journal of Social Theory 15(4): 427453.

Baumann, Shyon. 2001. "Intellectualization and Art World Development: Film in the United States." American Sociological Review 66(3): 404-426.

Beisel, Nicola. 1993. "Morals Versus Art: Censorship, The Politics of Interpretation, and the Victorian Nude." American Sociological Review 58(2): 145-162.

Benediktsson, Mike Owen. 2010. "The Deviant Organization and the Bad Apple CEO: Ideology and Accountability in Media Coverage of Corporate Scandals." Social Forces 88(5): 2189-2216.

Benson, Rodney, and Erik Neveu. 2005. Bourdieu and the Journalistic Field. Cambridge, UK: Polity Press.

Berbrier, Mitch. 1998. "“Half the Battle': Cultural Resonance, Framing Processes, and Ethnic Affectations in Contemporary White Separatist Rhetoric." Social Problems 45(4): 43150.

Bielby, William T., and Denise D. Bielby. 1994. “All Hits are Flukes: Institutionalized Decision Making and the Rhetoric of Network Prime-Time Program Development." American Journal of Sociology 99(5): 1287-1313.

Bijker, Wiebe E. 1995. Of Bicycles, Bakelites, and Bulbs: Toward a Theory of Sociotechnical Change. Cambridge: MIT Press.

Binder, Amy. 1993. “Constructing Racial Rhetoric: Media Depictions of Harm in Heavy Metal and Rap Music.” American Sociological Review 58(6): 753-767. 
Blumer, Herbert. 1971. "Social Problems as Collective Behavior." Social Problems 18(3): 298306.

Bourdieu, Pierre. 1984. Distinction: A Social Critique of the Judgement of Taste. Abingdon, Oxon: Routeledge.

Bourdieu, Pierre. 1993. The Field of Cultural Production. New York, NY: Columbia University Press.

Brissaud, Constantin, and Jean-Michel Chahsiche. 2017. "How to Become and International Intellectual? The Case of Thomas Piketty and 'Capital in the Twenty-First Century." Sociologica 11(1): 1-38

Brownstein, Ronald. 2001. "After the Attack; War on Terror Will Test U.S. in Terrible Ways" Los Angeles Times, September 17: A3.

Burawoy, Michael. 2005. "For Public Sociology,” American Sociological Review 70(1):4-28.

Calhoun, Craig Jackson. 2004. Toward a More Public Social Science. New York, NY: Social Science Research Council.

Camic, Charles. 1992. "Reputation and Predecessor Selection: Parsons and the Institutionalists," American Sociological Review 57(4):421-445.

Camic, Charles, and Neil Gross. 2001. "The New Sociology of Ideas.” Pp. 236-249 in Judith R. Blau (ed) The Blackwell Companion to Sociology. Malden, MA: Blackwell Publishing.

Camic, Charles, Neil Gross, and Michele Lamont. 2011. Social Knowledge in the Making. Chicago, IL: University of Chicago Press.

Chamless, John. 1994. "Why are so many people swinging at this curve ball?" The Dallas Morning News, October 29: 29.

Childress, C. Clayton. 2017. Under the Cover: The Creation, Production, and Reception of a Novel. Princeton, NJ: Princeton University Press.

Childress, C. Clayton, and Noah E. Friedkin. 2012. "Cultural Reception and Production: The Social Construction of Meaning in Book Clubs." American Sociological Review 77(1):45-68.

Cohen, Richard. 2001. "Beneath a Cloud of Death.” The Washington Post, September 12: A31.

Conley, Dalton. 2000. Honky. New York, NY: Vintage Books.

Coser, Lewis A., Charles Kadushin, and Walter W. Powell. 1982. Books: The Culture and 
Commerce of Publishing. Chicago, IL: University of Chicago Press.

DeVault, Marjorie L. 1990. "Novel Readings: The Social Organization of Interpretation." American Journal of Sociology 95(4): 887-921.

Desmond, Matthew. 2016. Evicted: Property and Profit in the American City. New York, NY: Crown Books Publishers.

DiMaggio, Paul. 1982. "Cultural Entrepreneurship in nineteenth-Century Boston." Media, Culture, and Society 4: 33-50.

Dubois, Vincent. 2017. "Policy Ethnography as a Combat Sport: Analyzing the Welfare State against the Grain." Pp. 184-202 in Didier Fassin (ed) If Truth Be Told: The Politics of Public Ethnography. Durham, NC: Duke University Press.

Duckworth, Angela. 2016. Grit: The Power of Passion and Perseverance. New York, NY: Simon and Schuster Inc.

Duneier, Mitchell. 1999. Sidewalk. New York, NY: Farrar, Straus, and Giroux.

Edin, Kathryn and Laura Lein. 1997. Making Ends Meet: How Single Mothers Survive Welfare and Low-Wage Work. New York, NY: Russell Sage Foundation.

Editorial. 1995. “On Dr. Foster” The Wall Street Journal, February 17: A10.

Emerson, B. 2002. "Ya-ya Brotherhood Forget Stardom; Guys are Forming Bands just for Fun. The Atlanta Journal-Constitution, August 25:2.

Epstein, Jason. 2001. Book Business. New York, NY: W.W. Norton.

Epstein, Steven. 2008. "Culture and Science/Technology: Rethinking Knowledge, Power, Materiality, and Nature." Annals of the American Academy of Political and Social Science 619(1): 165-182.

Fassin, Didier. 2017. If Truth be Told: The Politics of Public Ethnography. Durham, NC: Duke University Press.

Florida, Richard. 2002. The Rise of Creative Class: How it's Transforming Work, Leisure, Community and Everyday Life. New York, NY: Basic Books.

Florida, Richard. 2004. Cities and the Creative Class. New York, NY: Routledge.

Florida, Richard. 2005. The Flight of the Creative Class: The Global Competition for Talent. New York, NY: Harper Collins, 2005.

Florida, Richard. 2008. Who's Your City: How the Creative Economy is Making Where to Live the Most Important Decision of Your Life. New York, NY: Basic Books. 
Florida, Richard. 2010. The Great Reset: How New Ways of Living and Working Drive PostCrash Prosperity. New York, NY: Harper Collins.

Fine, Gary Alan. 1996. "Reputational Entrepreneurs and the Memory of Incompetence: Melting Supporters, Partisans Warriors, and Images of President Harding." American Journal of Sociology 101(5): 1159-1193.

Fine, Gary Alan, and Terence McDonnell. 2007. "Erasing the Brown Scare: Referential Afterlife and the Power of Memory Templates." Social Problems. 54(2): 170-187.

Fullbrook, Edward. 2006. Real World Economics: A Post-Autistic Economics Reader. London, UK: Anthem Press.

Gans, Herbert. 1980. Deciding What's News. New York, NY: Vintage Books.

Gans, Herbert J. 1989. "Sociology in America: The Discipline and the Public American Sociological Association, 1988 Presidential Address" American Sociological Review 54(1):1-16.

Gans, Herbert. 1998. "Best-Sellers by American Sociologists: An Exploratory Study" in Required Reading: Sociology's Most Influential Books ed. Dan Clawson, pp. 19-29. Amherst, MA: University of Massachusetts Press.

Gieryn, Thomas. 1999. Cultural Boundaries of Science: Credibility on the Line. Chicago, IL: University of Chicago Press.

Glassner, Barry. 1999. The Culture of Fear: Why Americans are Afraid of the Wrong Things. New York, NY: Basic Books.

Glassner, Barry. 2007. The Gospel of Food: Why We Should Stop Worrying and Enjoy What We Eat. New York, NY: Harper Collins.

Godbey, Geoffrey, and John Robinson. 1997. Time for Life: The Surprising Ways Americans Use their Time. Happy Valley PA: Pennsylvania State University Press.

Goffman, Erving. 1959. The Presentation of Self in Everyday Life. New York, NY: Anchor Books.

Goffman, Erving. 1981. Forms of Talk. Philadelphia: University of Pennsylvania Press.

Goffman, Alice. 2014. On the Run. Chicago, IL: University of Chicago Press.

Graham, Kristen A. 2000. "Light rail may forge closer ties" The Denver Post, July 22: B1.

Greco, Albert N. 1997. The Book Publishing Industry. Boston, MA: Allyn \& Bacon.

Griswold, Wendy. 1986. Renaissance Revivals: City Comedy and Revenge Tragedy in the 
London Theatre: 1576-1980. Chicago: University of Chicago Press.

Griswold, Wendy. 1987. "The Fabrication of Meaning: Literary Interpreation in the United States, Great Britain, and the West Indies." American Journal of Sociology 92(5): 10771117.

Griswold, Wendy. 2004 [1987]. Cultures and Societies in a Changing World. Thousand Oaks CA: Pine Forge Press.

Griswold, Wendy, Gemma Mangione, and Terence McDonnell. 2013. "Objects, Words, and Bodies in Space: Bringing Materiality into Cultural Analysis." Qualitative Sociology 36(4): 343-364.

Griswold, Wendy and Hannah Wohl. 2015. "Evangelists of Culture: One Book Programs and the Agents who Define Literature, Shape Tastes, and Reproduce Regionalism." Poetics 50:96-109.

Halbwachs M. 1992. On Collective Memory. Chicago, IL: University of Chicago Press.

Hartmann, Douglas. 2017. "Sociology and Its Publics: Rethinking Engagement and Revitalizing the Field." The Sociological Quarterly 58(1):3-18.

Herrnstein, Richard J., and Charles Murray. 1994. The Bell Curve: Intelligence and Class Structure in American Life. New York, NY: Free Press.

Hilgartner, Stephen. 1990. "The Dominant View of Popularization: Conceptual Problems, Political Uses." Social Studies of Science 20(3): 519-539.

Hilgartner, Stephen, and Charles L. Bosk. 1988. "The Rise and Fall of Social Problems: A Public Arenas Model.” American Journal of Sociology 94(1): 53-78.

Hirschman, Albert O. 1970. Exit, Voice, and Loyalty: Responses to Decline in Firms, Organizations, and States. Cambridge, MA: Harvard University Press.

Hochschild, Arlie. 1983. The Managed Heart: Commercialization of Human Feeling. Los Angeles, CA: The University of California Press.

Hochschild, Arlie. 1989. The Second Shift: Working Couples and the Revolution at Home. New York, NY: Penguin Books.

Hochschild, Arlie. 1997. The Time Bind: When Work Becomes Home and Home Becomes Work. New York, NY: Metropolitan Books.

Huntington, Samuel P. 1993. "The Clash of Civilizations?” Foreign Affairs 72(3): 22-49.

Huntington, Samuel P. 1996. The Clash of Civilizations and the Remaking of the World Order. 
New York, NY: Simon \& Schuster.

Isaac, Jeffrey. 2015. "For a More Public Political Science." Perspectives on Politics 13(2): 269-283.

Keller, Julia. 2002. "Hosting the hip may be the best urban plan" The Chicago Tribune, August 11: 1 .

Klinenberg, Eric. 2002. Heat Wave: A Social Autopsy of Disaster in Chicago. Chicago, IL: The University of Chicago Press.

Lamont, Michele. 1987. "How to Become a Dominant French Philosopher: The Case of Jacques Derrida" American Journal of Sociology 93(3):584-622.

Lamont, Michele. 1992. Money, Morals, and Manners: The Culture of the French and the American Upper-Middle Class. Chicago, IL: The University of Chicago Press.

Lareau, Annette. 2003. Unequal Childhoods: Class, Race, and Family Life. Berkeley, CA: University of California Press.

Latour, Bruno. 2005. Reassembling the Social: An Introduction to Actor-Network-Theory. Oxford, UK: Oxford University Press.

Lena, Jennifer C. 2012. Banding Together: How Communities Create Genres in Popular Music. Princeton, NJ: Princeton University Press.

Lena, Jennifer C., and Richard A. Peterson. 2008. "Classification as Culture: Types and Trajectories of Music Genres.” American Sociological Review 73(5): 697-718.

Longhofer, Wesley, Shannon Golden, and Arturo Baiocchi. 2010. "A Fresh Look at Sociology Bestsellers." Contexts 9(2): 18-28.

McDonnell, Terence E. 2010. "Cultural Objects as Objects: Materiality, Urban Space, and the Interpretation of AIDS Campaigns in Accra, Ghana." American Journal of Sociology 115(6): 1800-1852.

McDonnell, Terence E., Christopher Bail, and Iddo Tavory. 2017. "A Theory of Resonance." Sociological Theory 35(1): 1-14.

McDonnell, Terence E., Amy Jonason, and Kari Christoffersen. 2017. "Seeing Red and Wearing Pink: Trajectories of Cultural Power in the AIDS and Breast Cancer Ribbons." Poetics 60: 1-15.

McLaughlin, Neil. 1998. "How to Become a Forgotten Intellectual: Intellectual Movements and the Rise and fall of Erich Fromm." Sociological Forum 13(2): 215-246.

Mizruchi, Mark S. and Lisa C. Fein. 1999. "The Social Construction of Organizational 
Knowledge: A Study of the Uses of Coercive, Mimetic, and Normative Isomorphism.” Administrative Science Quarterly 44(4):653-683.

Moberg, David. 1992. “The American Worker's Lengthening Treadmill” Newsday, February 4: 46.

Molotch, Harvery, and Marilyn Lester. 1974. "News as Purposive Behavior: On the Strategic Use of Routine Events, Accidents, and Scandals.” American Sociological Review 39(1): 101-112.

Murray, Charles. 1997. What it Means to be Libertarian. New York, NY: Broadway Books.

Murray, Charles. 2003. Human Accomplishment: The Pursuit of Excellence in the Arts and Sciences 800 BC to 1950. New York, NY: Harper Collins.

No Author Listed. 1997. "Hardcovers in Brief” The Washington Post, September 14: X13.

Osnos, Evan. 2002. “24-hour News Stokes Nation's Fear Factor; Fixation on Terror Merges Information and Entertainment" The Chicago Tribune, November 11:9.

Peirce, Charles S. (1903) 1991. Pragmatism as a Principle and Method of Right Thinking: The 1903 Harvard Lectures on Pragmatism. Albany, NY: SUNY Press.

Piketty, Thomas. 2014. Capital in the $21^{\text {st }}$ Century. Cambridge, MA: Harvard University Press.

Pinch, Trevor J., and Wiebe Bijker. 1987. "The Social Construction of Facts and Artifacts." In Wiebe Bijker, Thomas Hughes, and Trevor Pinch (eds) The Social Construction of Technological Systems. Cambridge, MA: MIT Press.

Putnam, Robert D. 1995. "Bowling Alone: America's Declining Social Capital.” Journal of Democracy 6(1): 65-78.

Putnam, Robert D. 2000. Bowling Alone: The Collapse and Revival of American Community. New York, NY: Simon and Schuster.

Putnam, Robert D., and Lewis Feldstein. 2003. Better Together: Restoring the American Community. New York, NY: Simon and Schuster.

Ragin, Charles C. 1994. Constructing Social Research. Thousand Oaks CA: Pine Forge Press.

Santana-Acuna, Alvaro. 2014. "How a Literary Work becomes a Classic: The case of One Hundred Years of Solitude." American Journal of Cultural Sociology 2(1): 97-149.

Riesman, David. 1950. “Listening to Popular Music.” American Quarterly 2(4): 359-371. 
Saffron, Inga. 1992. "Hillary Clinton; Role Model; For Years, She - like other working women has Juggled Responsibilities; as Wife, Mother and Professional. Now, the Nation's Women will be Watching; as She Revamps the Job of First Lady. It'll be Another Tough Balancing Act." The Philadelphia Inquirer, December 6: L1.

Santoro, Marco, and Gisele Sapiro. 2017. "On the Social Life of Ideas and the Persistence of the Author in the Social and Human Sciences." Sociologica 11(1): 1-12.

Schor, Juliet. 1992. The Overworked American: The Unexpected Decline of Leisure. New York, NY: Basic Books.

Schor, Juliet. 1998. The Overspent American: Why We Want What We Don't Need. New York, NY: Basic Books.

Schudson, Michael. 1989. "How Culture Works: Perspectives from Media Studies on the Efficacy of Symbols." Theory and Society 18(2): 153-180.

Schudson, Michael. 2011 [2003]. The Sociology of News. New York, NY: W.W. Norton \& Company.

Shively, JoEllen. 1992. "Cowboys and Indians: Perceptions of Western Film among American Indians and Anglos." American Sociological Review 57(6): 725-739.

Stein, Arlene, and Jessie Daniels. 2017. Going Public: A Guide for Social Scientists. Chicago, IL: University of Chicago Press.

Sternheimer, Karen. 2017. The Social Scientist's Soapbox: Adventures in Writing Public Sociology. New York, NY: Routledge.

Swidler, Ann. 1986. "Culture in Action: Symbols and Strategies." American Sociological Review 51(2): 273-286.

Swidler, Ann, and Jorge Arditi. 1994. "The New Sociology of Knowledge." Annual Review of Sociology 20: 305-329.

Tavory, Iddo, and Stefan Timmermans. 2012. "Theory Construction in Qualitative Research From Grounded Theory to Abductive Analysis." Sociological Theory 30(3): 167-186.

Tavory, Iddo, and Stefan Timmermans. 2014. Abductive Analysis: Theorizing Qualitative Research. Chicago, IL: University of Chicago Press.

Tuchman, Gaye. 1978. Making News: A Study in the Construction of Reality. New York, NY: The Free Press.

Wagner-Pacifici, Robin, and Barry Schwartz. 1991. "The Vietnam Veterans Memorial: Commemorating a Difficult Past.” American Journal of Sociology 97(2): 376-420. 
Weeks, Jerome. 2003. "A Best is a Best is a Best is a Best - 'Accomplishment' Collapses on Itself” The Dallas Morning News, December 7: 9G.

Wilson, William J. 1996. When Work Disappears: The World of the New Urban Poor. New York, NY: Vintage Books.

Will, George. 1995. "Democracy Is Healthy If Bowling Leagues Are.” Newsday, January 5: A36.

Wilson, Craig. 2006. “'Barefoot Home' Brings Outdoors In” USA Today, October 6: D11.

Winegar, Karen. 1992. “Take a Break // Don't Just Eat lunch - Exercise, See a Film, Cavort, Go Waltzing” Minneapolis Star Tribune, April 29: 1E.

Winton, Richard and Rong-Gon Lin II. 2005. "Police Seek to Reassure Motorists; LAPD, CHP Officials are Concerned that Growing Public Apprehension Over Freeway Shootings is out of Proportion to the Actual Threat" Los Angeles Times, May 4: B1.

Wuthnow, Robert. Communities of Discourse: Ideology and Social Structure in the Reformation, the Enlightenment, and European Socialism. Cambridge, MA: Harvard University Press.

Young, Michael. 1958. The Rise of the Meritocracy. New York, NY: Thames and Hudson.

Zernike, Kate. 2004. "First, Your Water Was Filtered. Now It's Your Life” New York Times, March 21: 4.4. 
$\underline{\text { Table 1. Publishing, Citation, Sales, and Newspaper Hits }}{ }^{19}$

\begin{tabular}{|c|c|c|c|c|c|c|}
\hline Author & Book Title & Publisher & Year & $\begin{array}{l}\text { Citations } \\
\quad(\mathrm{GS})\end{array}$ & $\begin{array}{l}\text { Sales } \\
(1000)\end{array}$ & Hits \\
\hline $\begin{array}{l}\text { Herrnstein } \\
\text { and Murray }\end{array}$ & $\begin{array}{l}\text { Bell Curve: Intelligence and } \\
\text { Class Structure in American } \\
\text { Life. }\end{array}$ & Free Press & 1994 & 8,089 & NA & 387 \\
\hline Putnam & $\begin{array}{l}\text { Bowling Alone: The Collapse } \\
\text { and Revival of American } \\
\text { Community. }\end{array}$ & $\begin{array}{l}\text { Simon \& } \\
\text { Schuster }\end{array}$ & $\begin{array}{c}2000 \\
(1995)\end{array}$ & 39,098 & NA & 237 \\
\hline Florida & $\begin{array}{l}\text { Rise of the Creative Class: } \\
\text { How It's Transforming Work, } \\
\text { Leisure, Community, and } \\
\text { Everyday Life. }\end{array}$ & Basic Books & 2002 & 17,209 & NA & 205 \\
\hline Schor & $\begin{array}{l}\text { The Overworked American: } \\
\text { The Unexpected Decline of } \\
\text { Leisure. }\end{array}$ & Basic Books & 1992 & 3,888 & NA & 154 \\
\hline Huntington & $\begin{array}{l}\text { The Clash of Civilizations and } \\
\text { the Remaking of World Order. }\end{array}$ & $\begin{array}{l}\text { Simon \& } \\
\text { Schuster }\end{array}$ & $\begin{array}{c}1996 \\
(1993)\end{array}$ & 18,140 & NA & 123 \\
\hline Glassner & $\begin{array}{l}\text { The Culture of Fear: Why } \\
\text { Americans are Afraid of the } \\
\text { Wrong Things. }\end{array}$ & Basic Books & 1999 & 1,367 & 50 & 100 \\
\hline Hochschild & $\begin{array}{l}\text { The Second Shift: Working } \\
\text { Families and the Revolution at } \\
\text { Home. }\end{array}$ & Avon Books & 1989 & 7,264 & NA & 88 \\
\hline Wilson & $\begin{array}{l}\text { When Work Disappears: The } \\
\text { World of the New Urban Poor }\end{array}$ & Vintage Books & 1996 & 6,397 & $5-10$ & 37 \\
\hline Klinenberg & $\begin{array}{l}\text { Heat Wave: A Social Autopsy } \\
\text { of Disaster in Chicago }\end{array}$ & $\begin{array}{l}\text { University of } \\
\text { Chicago }\end{array}$ & 2002 & 1,518 & $5-10$ & 36 \\
\hline Anderson & $\begin{array}{l}\text { Code of the Street: Decency, } \\
\text { Violence, and the Moral Life } \\
\text { of the Inner City }\end{array}$ & $\begin{array}{l}\text { W. W. Norton } \\
\text { \& Company }\end{array}$ & 1999 & 4,480 & $10-20$ & 32 \\
\hline Duneier & Sidewalk & $\begin{array}{l}\text { Farrar, Straus } \\
\text { and Giroux }\end{array}$ & 1999 & 1,385 & $5-10$ & 28 \\
\hline Conley & Honky & $\begin{array}{l}\text { University of } \\
\text { California }\end{array}$ & 2000 & 1,125 & $10-20$ & 26 \\
\hline Lareau & $\begin{array}{l}\text { Unequal Childhoods: Class, } \\
\text { Race and Family Life }\end{array}$ & $\begin{array}{l}\text { University of } \\
\text { California }\end{array}$ & 2003 & 4,632 & $10-20$ & 11 \\
\hline Edin & $\begin{array}{l}\text { Making Ends Meet: How } \\
\text { Single Mothers Survive } \\
\text { Welfare and Low-Wage Work }\end{array}$ & $\begin{array}{l}\text { Russell Sage } \\
\text { Foundation }\end{array}$ & 1997 & 2,209 & NA & 6 \\
\hline Bourdieu & $\begin{array}{l}\text { Distinction: A Social Critique } \\
\text { of the Judgement of Taste }\end{array}$ & $\begin{array}{l}\text { Harvard } \\
\text { University }\end{array}$ & 1984 & 46,035 & NA & 5 \\
\hline
\end{tabular}

${ }^{19}$ Bowling Alone and Clash of Civilizations were first published in academic journal articles, Bowling Alone in Journal of Democracy in 1995, and Clash of Civilizations in Foreign Affairs in 1993. We discuss in turn. Google citations reflect numbers at the time of data collection. 
Table 2. Search Results for Standard and Full Text or Extended Abstract

\begin{tabular}{lll}
\hline Public Idea & Standard & Full Text/Extended Abstract \\
\hline Bell Curve & 387 & 305 \\
Bowling Alone & 237 & 223 \\
Clash of Civilizations & 123 & 114 \\
Creative Class & 205 & 176 \\
Culture of Fear & 100 & 99 \\
Overworked American & 154 & 131 \\
Second Shift & 88 & 73 \\
\hline Total & 1294 & 1121 \\
\hline
\end{tabular}

$\underline{\text { Table 3. Author and Publisher Characteristics }}^{20}$

\begin{tabular}{|c|c|c|c|c|}
\hline Author & Book & Institution & Publisher & 2nd Edition \\
\hline Herrnstein & Bell Curve & Harvard University & Free Press & NA \\
\hline Murray & & $\begin{array}{l}\text { American Enterprise } \\
\text { Institute }\end{array}$ & & \\
\hline Putnam & Bowling Alone & Harvard University & $\begin{array}{l}\text { Simon \& } \\
\text { Schuster }\end{array}$ & NA \\
\hline Florida & $\begin{array}{l}\text { The Rise of the } \\
\text { Creative Class }\end{array}$ & Carnegie Mellon & Basic Books & 2012 \\
\hline Huntington & $\begin{array}{l}\text { The Clash of } \\
\text { Civilizations }\end{array}$ & Harvard University & $\begin{array}{l}\text { Simon \& } \\
\text { Schuster }\end{array}$ & NA \\
\hline Schor & $\begin{array}{l}\text { The Overworked } \\
\text { American }\end{array}$ & Harvard University & Basic Books & NA \\
\hline Glassner & The Culture of Fear & $\begin{array}{l}\text { University of Southern } \\
\text { California }\end{array}$ & Basic Books & NA \\
\hline Hochschild & The Second Shift & $\begin{array}{c}\text { University of California - } \\
\text { Berkeley }\end{array}$ & Avon Books & 1997 \\
\hline
\end{tabular}

${ }^{20}$ For simplicity, we list the book publisher. As mentioned in footnote seven, Bowling Alone (1995) and Clash of Civilizations (1993) were initially published in journal articles. 
$\underline{\text { Table 4. A Typology of Public Ideas }}$

\begin{tabular}{|c|c|c|c|c|}
\hline \multirow{5}{*}{ 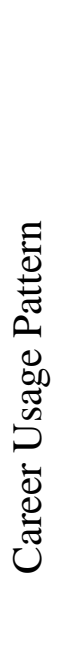 } & & \multicolumn{3}{|c|}{ Career Hit Pattern } \\
\hline & & Splashers & Coasters & Risers \\
\hline & $\begin{array}{l}\text { Object } \\
\text { Heavy }\end{array}$ & - bell curve & $\ldots$ & $\ldots$ \\
\hline & Balanced & ... & - $\quad$ second shift & $\ldots$ \\
\hline & $\begin{array}{c}\text { Interpretant } \\
\text { Heavy }\end{array}$ & .. & $\begin{array}{l}\text { - } \text { culture of fear } \\
\text { overworked } \\
\text { American } \\
\text { - creative class }\end{array}$ & $\begin{array}{ll}\text { - } & \text { clash of } \\
\text { civilizations } \\
\text { - } & \text { bowling alone }\end{array}$ \\
\hline
\end{tabular}




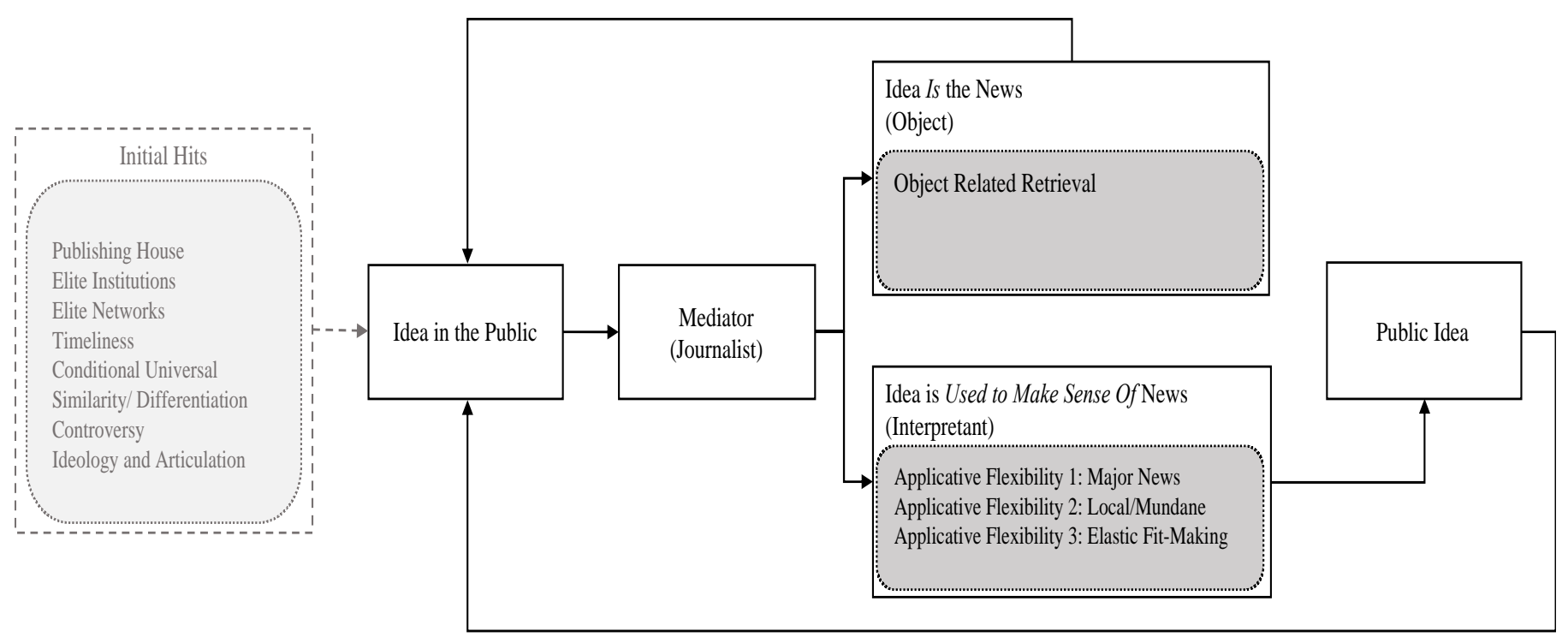

Figure 2. Aggregate Full Text Usage for all Ideas ( $N=1121)$

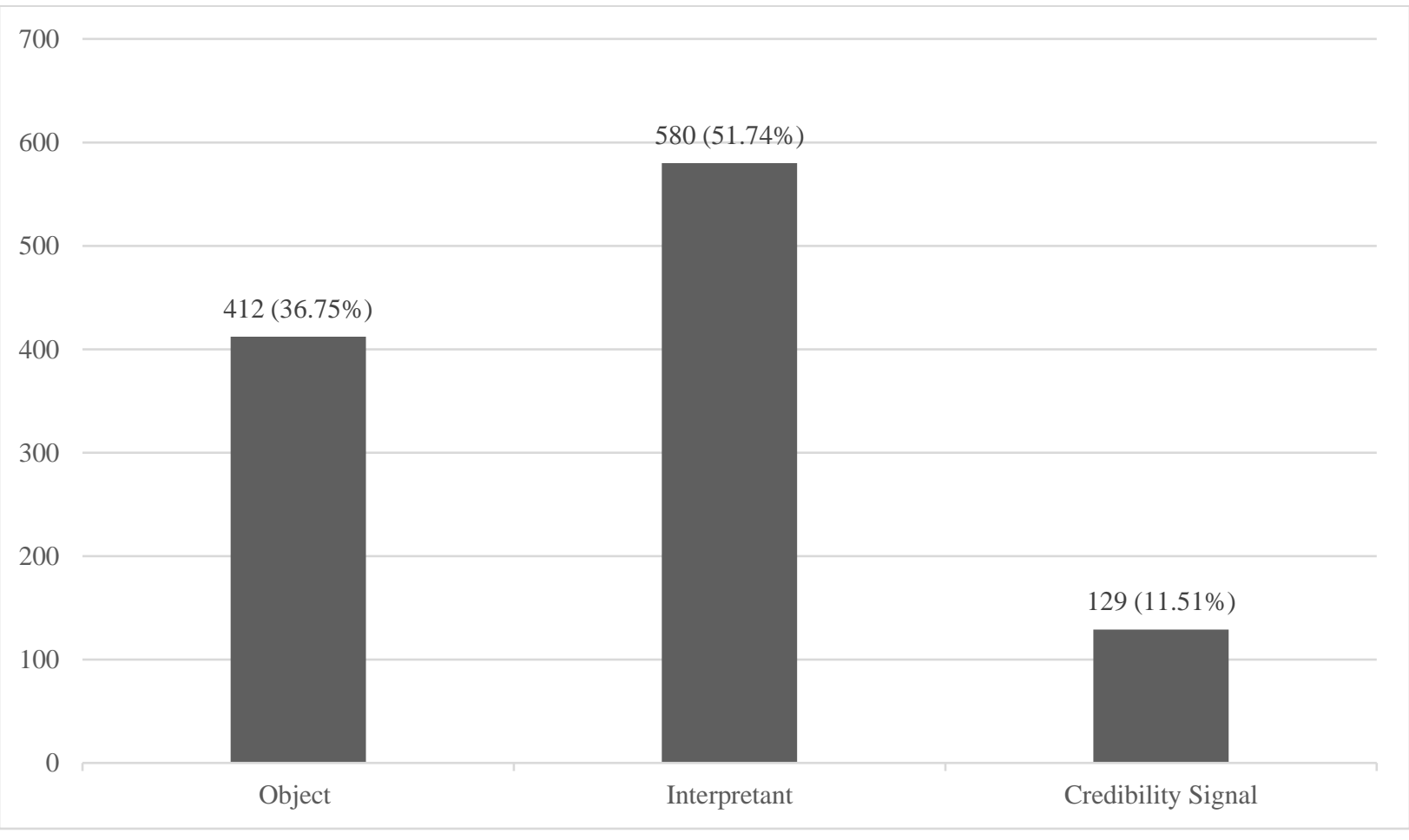


Figure 3. Bell Curve Full Text Career Hits and Usage over Time ( $\mathrm{N}=305)$

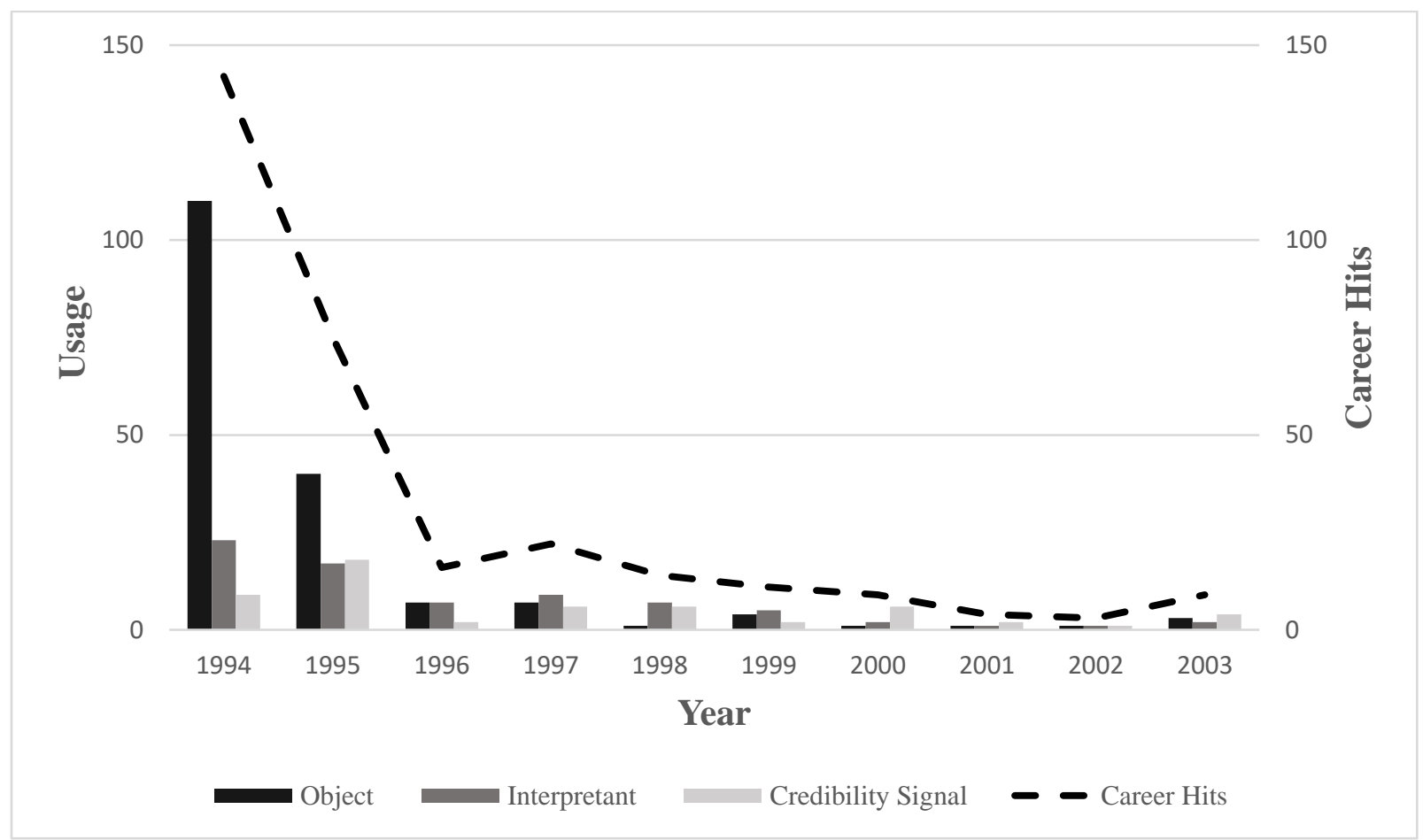

Figure 4. Second Shift Full Text Career Hits and Usage over Time (N=73)

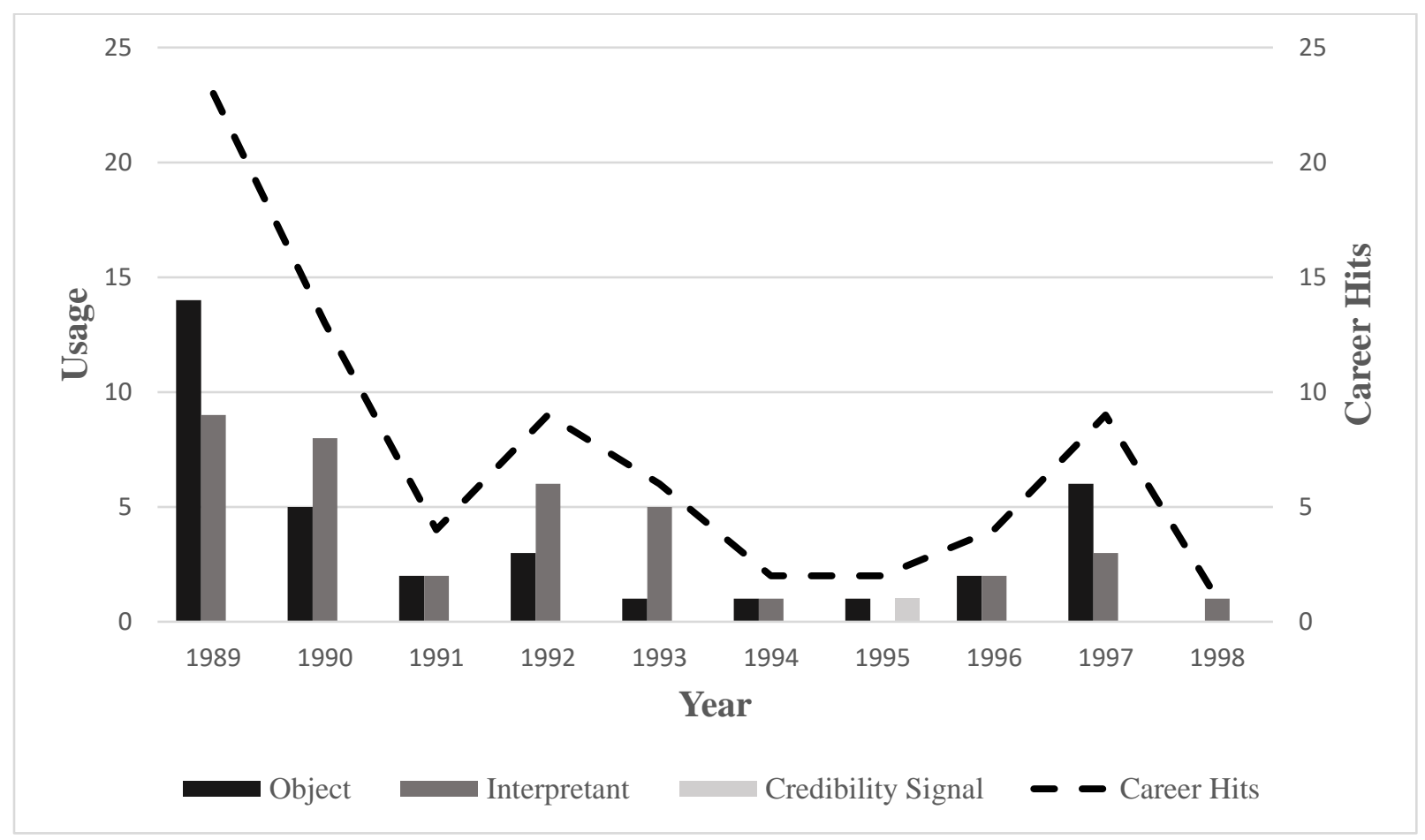


Figure 5. Culture of Fear Full Text Career Hits and Usage over Time (N=99)

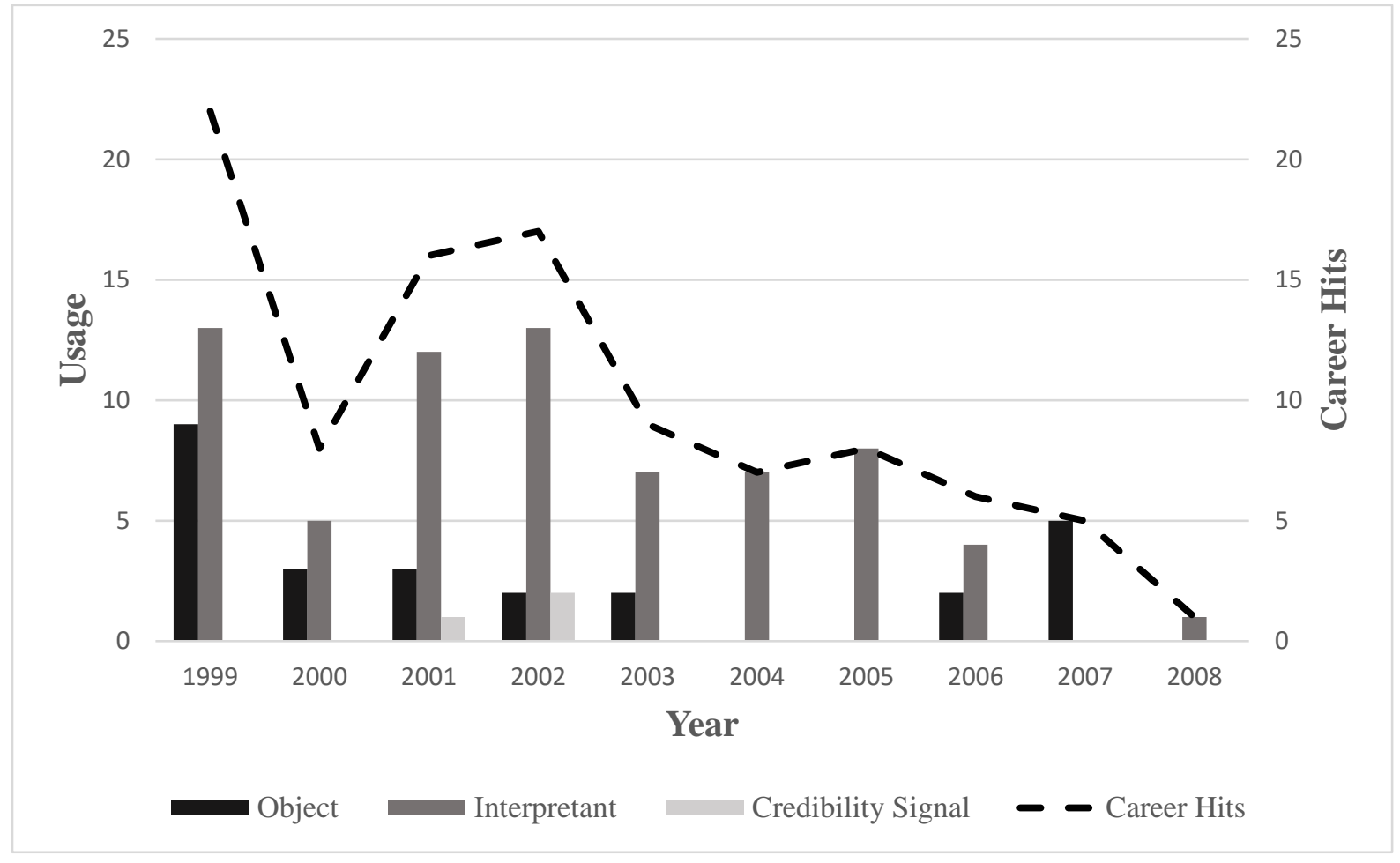

Figure 6. Overworked American Full Text Career Hits and Usage over Time (N=131)

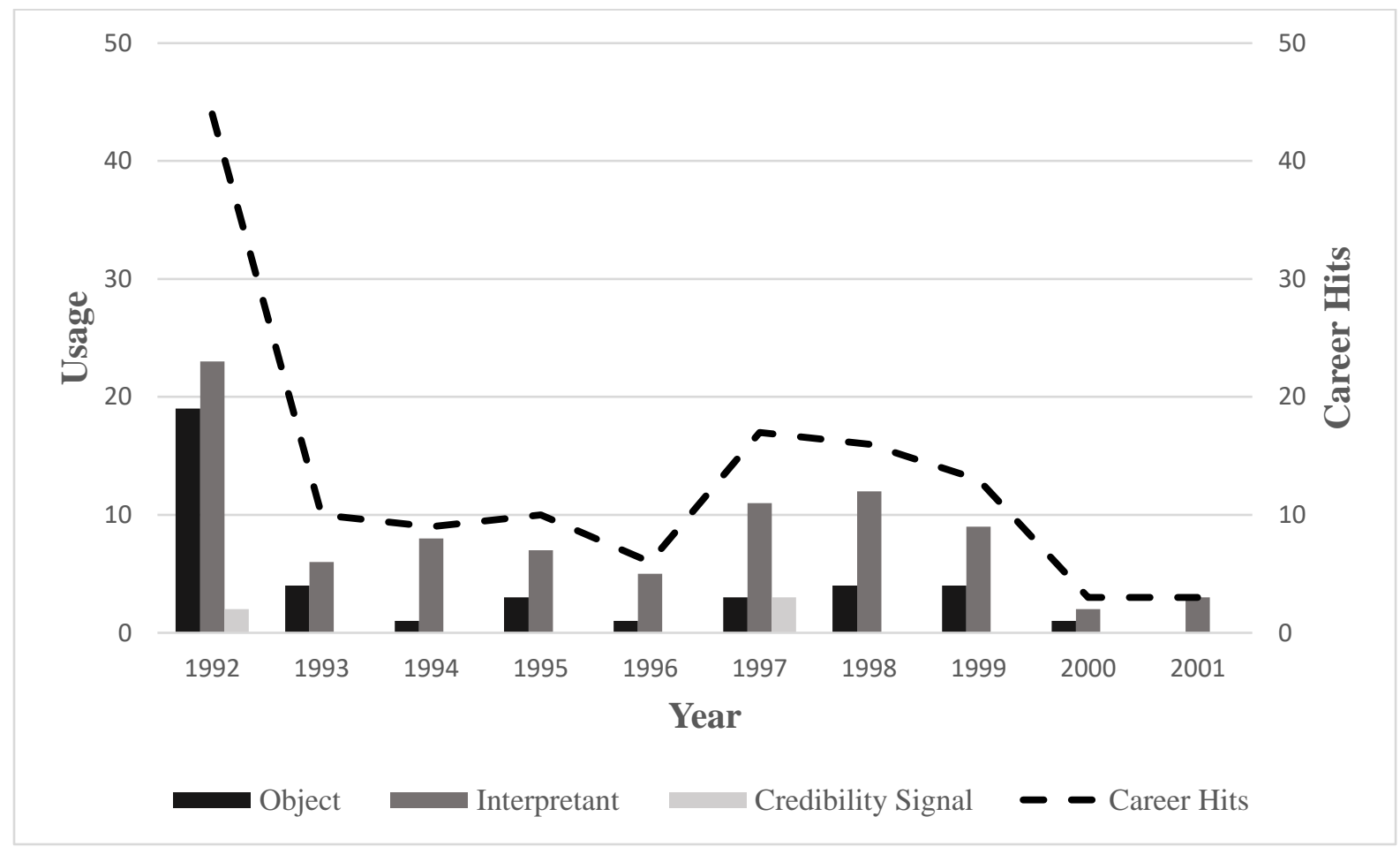


Figure 7. Creative Class Full Text Career Hits and Usage over Time (N=176)

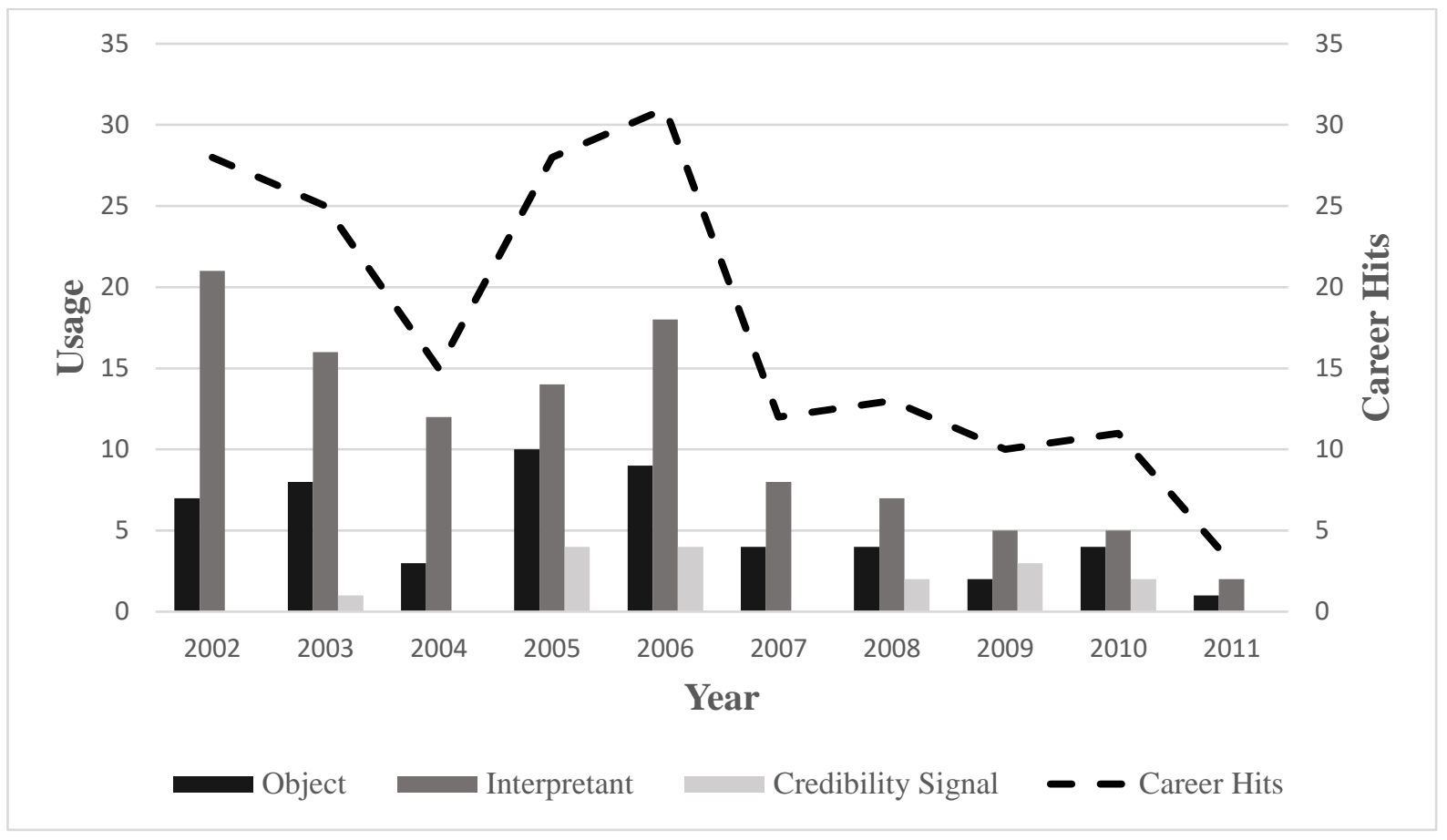

Figure 8. Clash of Civilizations Full Text Career Hits and Usage over Time ( $\mathrm{N}=114)$

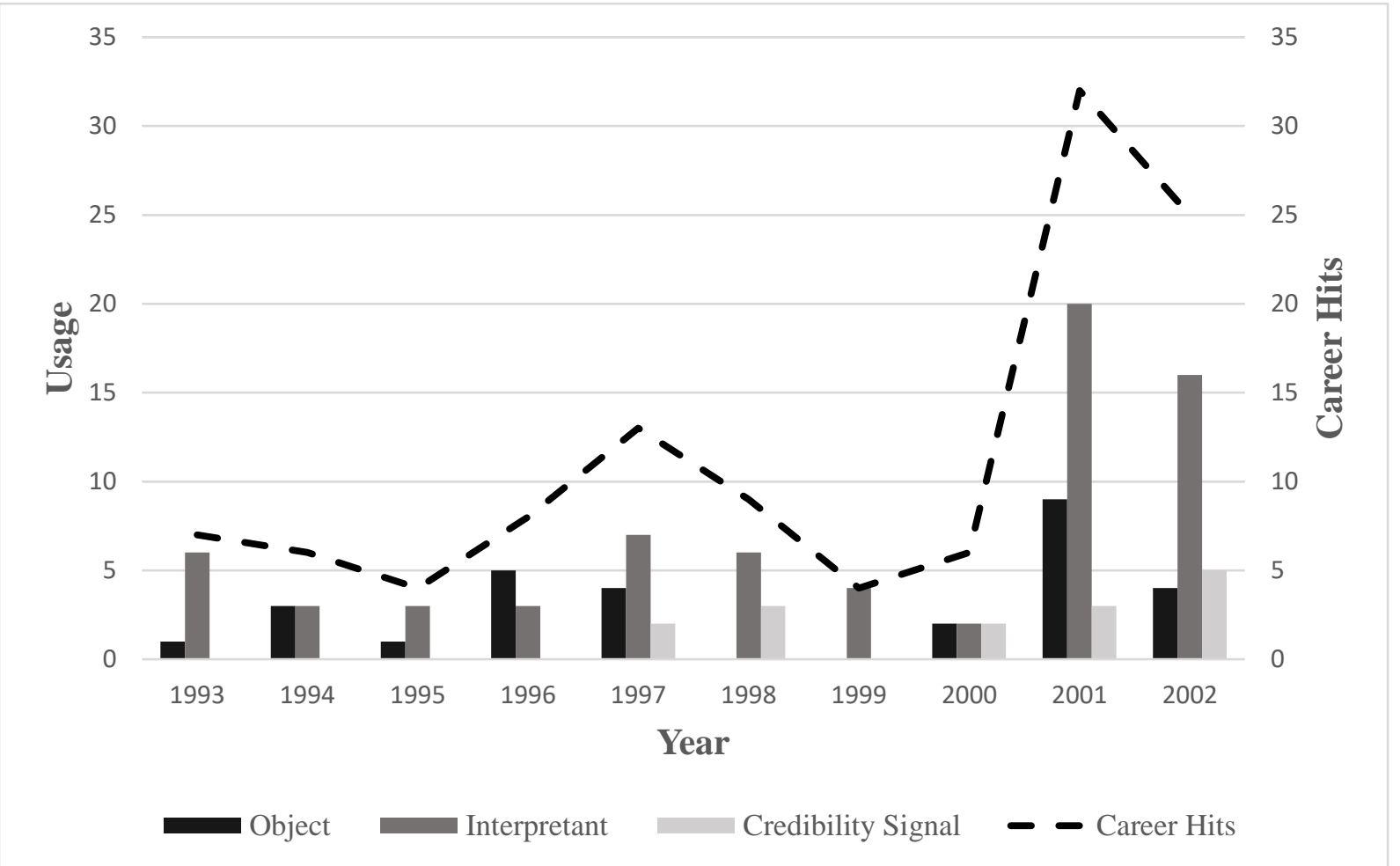


Figure 9. Bowling Alone Full Text Career Hits and Usage over Time

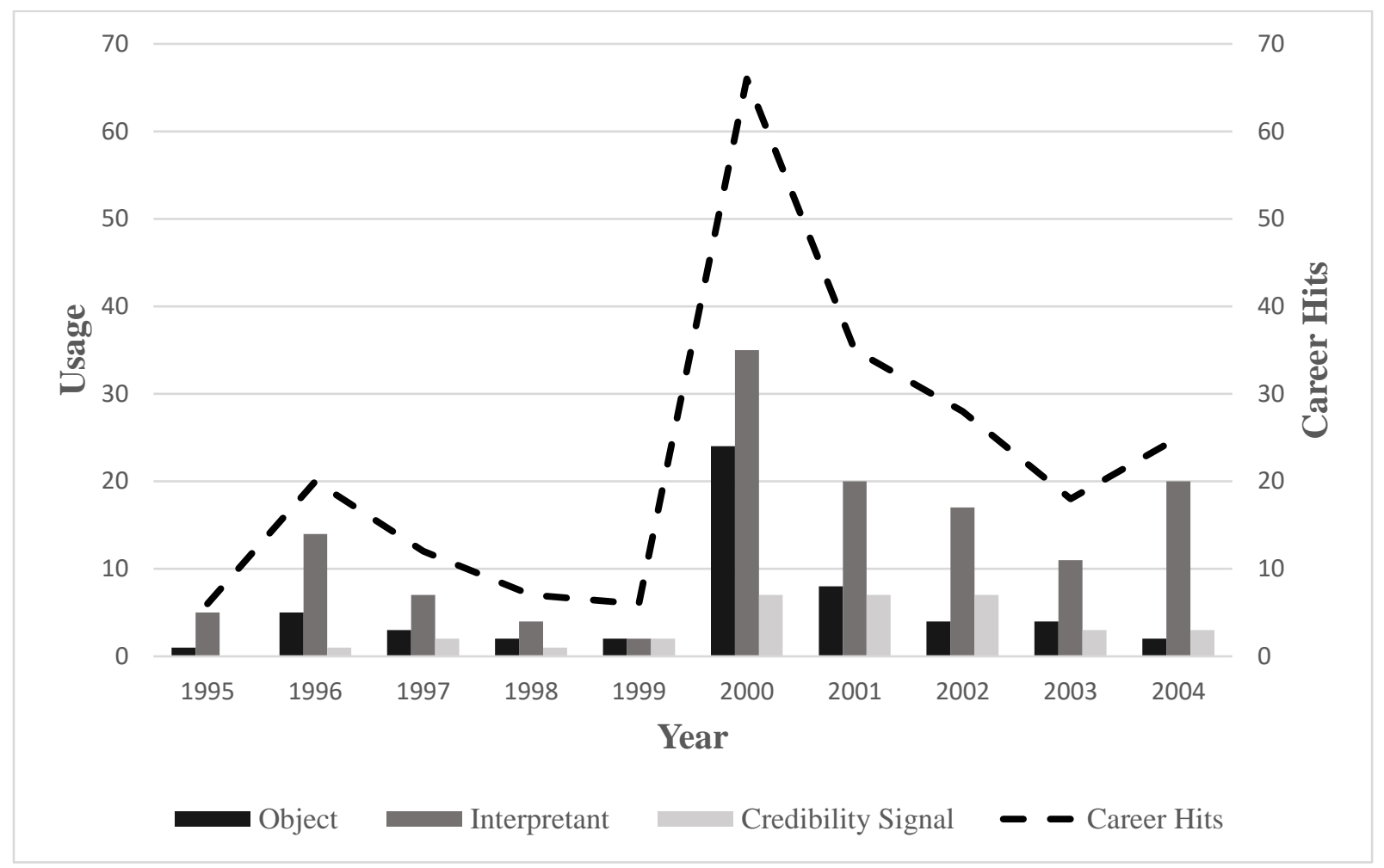

